HYDROLOGIC APPRAISAL OF THE PINE BARRENS, SUFFOLK COUNTY, NEW YORK by Richard K. Krulikas

U.S. GEOLOGICAL SURVEY

Water-Resources Investigations Report 84-4271

Prepared in cooperation with

LONG ISLAND REGIONAL PLANNING BOARD

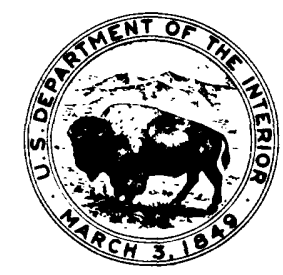

Syosset, New York

1986 


\section{UNITED STATES DEPARTMENT OF THE INTERIOR}

DONALD PAUL HODEL, Secretary

GEOLOGICAL SURVEY

Dallas L. Peck, Director

For additional information write to

U.S. Geological Survey

5 Aerial Way

Syosset, New York 11791

Telephone: (516) 938-8830
Copies of this report may be purchased from:

Open-File Services Section Western Distribution Branch

U.S. Geological Survey Box 25425, Federal Center Denver, Colorado 80225

Telephone: (303) 234-5888 
Abstract. . . . . . . . . . . . . . . . . . . . 1

Introduction. . . . . . . . . . . . . . . . . . . 1

Purpose and scope. . . . . . . . . . . . . . . . . 2

Previous studies . . . . . . . . . . . . . . . . . . 2

Method of investigation. . . . . . . . . . . . . . . 3

Acknowledgments. . . . . . . . . . . . . . . . . 3

General setting . . . . . . . . . . . . . . . . 6

Location and extent of area. . . . . . . . . . . 6

Land use ........................ . . 6

Population . . . . . . . . . . . . . . . . . . 6

Geohydrology. . . . . . . . . . . . . . . . . . . . 6

Geologic setting . . . . . . . . . . . . . . 6

Hydrology. . . . . . . . . . . . . . . . . . . 12

Precipitation . . . . . . . . . . . . . . . 12

Recharge and discharge of ground water. . . . . . . . 14

Flow subsystems and recharge zones. . . . . . . . . 14

Ground-water levels . . . . . . . . . . . . 15

Water table. .................. 18

Magothy aquifer.................... 18

Surface water . . . . . . . . . . . . 18

Water quality . . . . . . . . . . . . . . . . . 24

Public-supply wells . . . . . . . . . . . . . . . 24

Observation wells. . . . . . . . . . . . . . . 24

Private wells....................... . 24

Surface water. . . . . . . . . . . . . . . . 28

Sewage-treatment plants. . . . . . . . . . . . . . . . 28

Areas of point-source contamination. . . . . . . . . . . 32

Water use and pumpage . . . . . . . . . . . . . . . . . 34

Public-water supply. . . . . . . . . . . . . . . . . 34

Brookhaven National Laboratory water supply. . . . . . . . . . 35

Summary and conclusions . . . . . . . . . . . . . . . . 36

References cited. . . . . . . . . . . . . . . . . 37

\section{ILLUSTRATIONS}

Figure 1. Map showing major geographic features of Long Island and location of Pine Barrens................. 2

2. Map showing location of wells and streamflow-measurement sites in Pine Barrens and position of geologic sections shown in figure 5. . . . . . . . . . . . . . . . 4

3. Generalized geologic section of the Pine Barrens . . . . . 7

4. Map showing altitude of the top of the Magothy-Matawan

Formation, undifferentiated. . . . . . . . . . . 8

5. Geohydrologic sections $A-A^{\prime}, B-B^{\prime}$, and $C-C^{\prime}$ in the Pine

Barrens. . . . . . . . . . . . . . . . . . 


\section{ILLUSTRATIONS (continued)}

Page

Figure 6. Graphs showing average annual and average monthly

precipitation at Upton, 1943-82. . . . . . . . . .

7. Map showing approximate areas of shallow and deep groundwater flow subsystems. . . . . . . . . . . .

8. Long-term hydrographs for wells S3543, S5517, S6411, and s8835. . . . . . . . . . . . . . . . .

9. Map showing water-table altitude in the Pine Barrens,

September 1983 . . . . . . . . . . . . . . .

10. Map of potentiometric surface of Magothy aquifer in the Pine Barrens, September 1983 . . . . . . . . . .

11. Map showing locations of observation wells and private wells having nitrate-nitrogen concentrations greater than $10 \mathrm{mg} / \mathrm{L}$ and volatile organic chemical concentrations

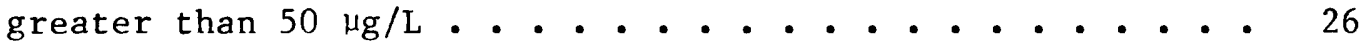

12. Map showing locations of point-source contamination. . . . 30

\section{TABLES}

Table 1. Geologic and hydrogeologic units in the Pine Barrens . . . 10

2. Nitrate-nitrogen concentrations greater than $10 \mathrm{mg} / \mathrm{L}$, and volatile organic chemical concentrations greater than 50 $\mu \mathrm{g} / \mathrm{L}$ in water samples from selected wells in the Pine Barrens, 1978-82 . . . . . . . . . . . . .

3. Concentrations of detergents (MBAS) in selected streams in the Pine Barrens, New York, 1982-83. . . . . . . . .

4. Industries that hold or haul wastewater in the Pine Barrens. 32

5. Industrial wastewater discharges in the Pine Barrens . . . 33

6. Estimated public-supply withdrawals by Suffolk County Water Authority and private well companies in the Pine Barrens, 1982 . . . . . . . . . . . . . . . . . .

7. Estimated public-supply withdrawals by Brookhaven National Laboratory, 1982 . . . . . . . . . . . . . . 36

8. Water levels in wells in the Pine Barrens, September, 1983 • 40

9. Discharge of selected streams in the Pine Barrens, 1982-83 . 42 


\section{TABLES (continued)}

Table 10. Concentrations of nitrate-nitrogen in water from selected Suffolk County Department of Health Services observation wells in the Pine Barrens, 1972-82.......... . 44

11. Sewage-treatment plants in the Pine Barrens. . . . . . . 50

12. Documented point sources of ground-water contaminants in the Pine Barrens . . . . . . . . . . . . . . 52

\section{CONVERSION FACTORS AND ABBREVIATIONS}

Multiply inch-pound units

foot ( $f t$ )
square mile (mi2)
gallon (gal)
cubic foot per second
(ft $3 / \mathrm{s}$ )
gallon per minute (gal/min)
gallon per day (gal/d)
million gallons per day
(Mgal/d)

by

To obtain SI units

Length

0.3048 meter (m)

$\underline{\text { Area }}$

2.590

square kilometer $\left(\mathrm{km}^{2}\right)$

Volume

0.003785 cubic meter $\left(\mathrm{m}^{3}\right)$

F low

0.02832

0.06308

0.003785

0.04381 cubic meter per second

$$
\left(\mathrm{m}^{3} / \mathrm{s}\right)
$$

liter per second (L/s)

cubic meter per day $\left(\mathrm{m}^{3} / \mathrm{d}\right)$

cubic meter per second

\section{Abbreviation}

picocuries per liter ( $p c i / L)$ 


\title{
HYDROLOGIC APPRAISAL OF THE PINE BARRENS, SUFFOLK COUNTY, NEW YORK
}

\author{
by Richard K. Krulikas
}

\begin{abstract}
The ground-water resources of the Pine Barrens, in southeastern Suffolk County, were appraised during 1982-83 for their potential for use as a supply of potable water. The study area encompasses approximately 50 square miles. The Precambrian bedrock is overlain by Cretaceous, Pleistocene, and Holocene deposits. The surficial material consists of morainal and outwash deposits overlain by recent beach and marsh deposits.
\end{abstract}

The ground-water reservoir consists of three aquifers--the Lloyd and the Magothy of Cretaceous age and the upper glacial of Pleistocene age. The water is generally of suitable quality for drinking and most other uses except in several localized spots where point-source contamination has been documented.

Precipitation is the sole source of recharge. Average annual precipitation recorded in the area during 1943-82 was 43 inches, about half of which reaches the ground-water reservoir. Overland runoff is estimated to be 0.5 inches per year, and evapotranspiration 23 inches per year.

Total public water-supply withdrawal in the area in 1982 is estimated to have been 9.09 million gallons per day (Mgal/d). The upper glacial aquifer is the major source of public water; pumpage in 1982 was $7.88 \mathrm{Mgal} / \mathrm{d}$; pumpage from the Magothy was $1.02 \mathrm{Mgal} / \mathrm{d}$, and pumpage from the Lloyd aquifer was $0.19 \mathrm{Mgal} / \mathrm{d}$.

Stream discharge is measured periodically at 17 streamflowmeasurement sites on the 11 streams in the Pine Barrens.

\section{INTRODUCTION}

More than 2.8 million people on Long Island depend on ground water for drinking water and most other uses. Long Island's aquifers have been designated as "sole source" by the U.S. Environmental Protection Agency. Increasing urbanization and industrialization have altered the quality of water in parts of the aquifers, and some of the water has become impotable. Ground-water planners and managers are, therefore, in search of areas of high-quality potable ground water.

One area proposed as a source of high-quality ground water is a part of Long Island's Pine Barrens in southeastern Suffolk County (fig. 1), which is a relatively undisturbed woodland of pine and oak. Because this is the least populated and least industrialized part of the island, its ground water is probably of high quality. Proper development and management of this natural resource and protection of its quality will require thorough understanding of the geohydrologic environment and its chemical characteristics. 


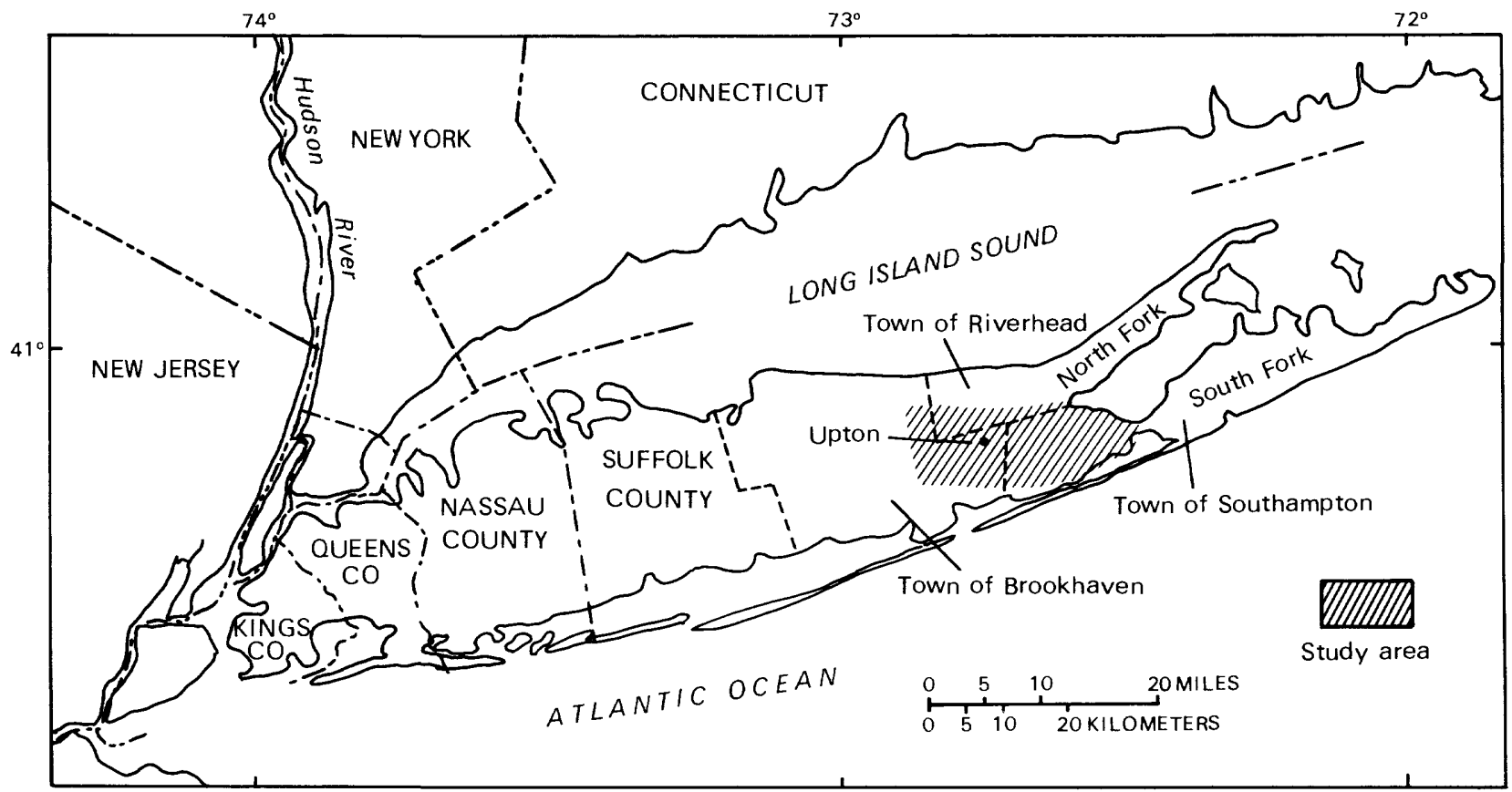

Base from U.S. Geologıcal Survey

State base map, 1:500,000, 1974

Figure 1.--Major geographic features of Long Island and Zocation of Pine Barrens.

\section{Purpose and Scope}

From April 1982 through September 1983, the U.S. Geological Survey investigated the water resources of the Pine Barrens in cooperation with the Long Island Regional Planning Board to (1) describe the geohydrologic units and their relationships; (2) delineate the occurrence and movement of fresh ground water and surface water; and (3) evaluate the chemical quality of several selected properties and constituents of the water in the major aquifers, and (4) identify areas of point-source contamination.

This report summarizes the results of most aspects of the study. Pertinent data on the geology and hydrology of the area are shown on a series of maps, geologic sections, and hydrographs of wells. Certain water-management implications are discussed in the context of these data.

\section{Previous Studies}

The geology of the Pine Barrens and the surrounding area were first studied by Fuller (1914); his report describes the Pleistocene units and 
includes a surficial geologic map. A later description of the subsurface geology (including ground water) is presented in Suter, delaguna, and Perlmutter (1949). Others who have written on the geology and ground water of the area are Holzmacher, McLendon, and Murrel1 (1968) and Jensen and Soren (1974).

Several water-table maps of Long Island that include the Pine Barrens have been published, including Nakao and Erlichman (1978) for 1975 and Donaldson and Koszalka (1982a, b, c) for 1979.

Other hydrologic investigations of this area are described by Cohen, Franke, and McClymonds (1969), who studied the effects of the 1962-66 drought; Prince (1976), who depicted the potentiometric surface of the Magothy aquifer; and Donaldson and Koszalka (1982a, b, c), who depicted the water-table altitude and the potentiometric surface of the Lloyd and Magothy aquifers. Some of the streamflow and water-quality data presented herein have been published by the U.S. Geological Survey (1981, 1982, 1983).

\section{Method of Investigation}

Wells in the Pine Barrens were inventoried to determine which would be most suitable for water-level measurements. An additional 21 wells were drilled to improve the observation-well network. (These additional wells are those having well numbers greater than S74287.) Locations of all hydrologic data sites are shown in figure 2 .

Ground-water levels in the upper glacial (water-table) aquifer were measured from April 1982 through September 1983. Water-level data from 112 observation wells measured in September 1983 were used to make a water-table map (fig. 9), and water-level data from five wells screened in the underlying Magothy aquifer were used to make a potentiometric-surface map (fig. 10). All water-level data are given in table 8 (at end of report). All well measurements were adjusted to sea level to uniformly define the water-table and potentiometric-surface altitude.

Ground-water and surface-water samples were analyzed for physical and chemical properties. The analyses were made by the Suffolk County Department of Health Services and the Suffolk County Water Authority.

\section{Acknowledgments}

The author thanks Vito Minei of the Suffolk County Department of Health Services for supplying all pertinent water-quality data, and the Suffolk County Water Authority and the New York State Department of Conservation for supplying pumpage data. 


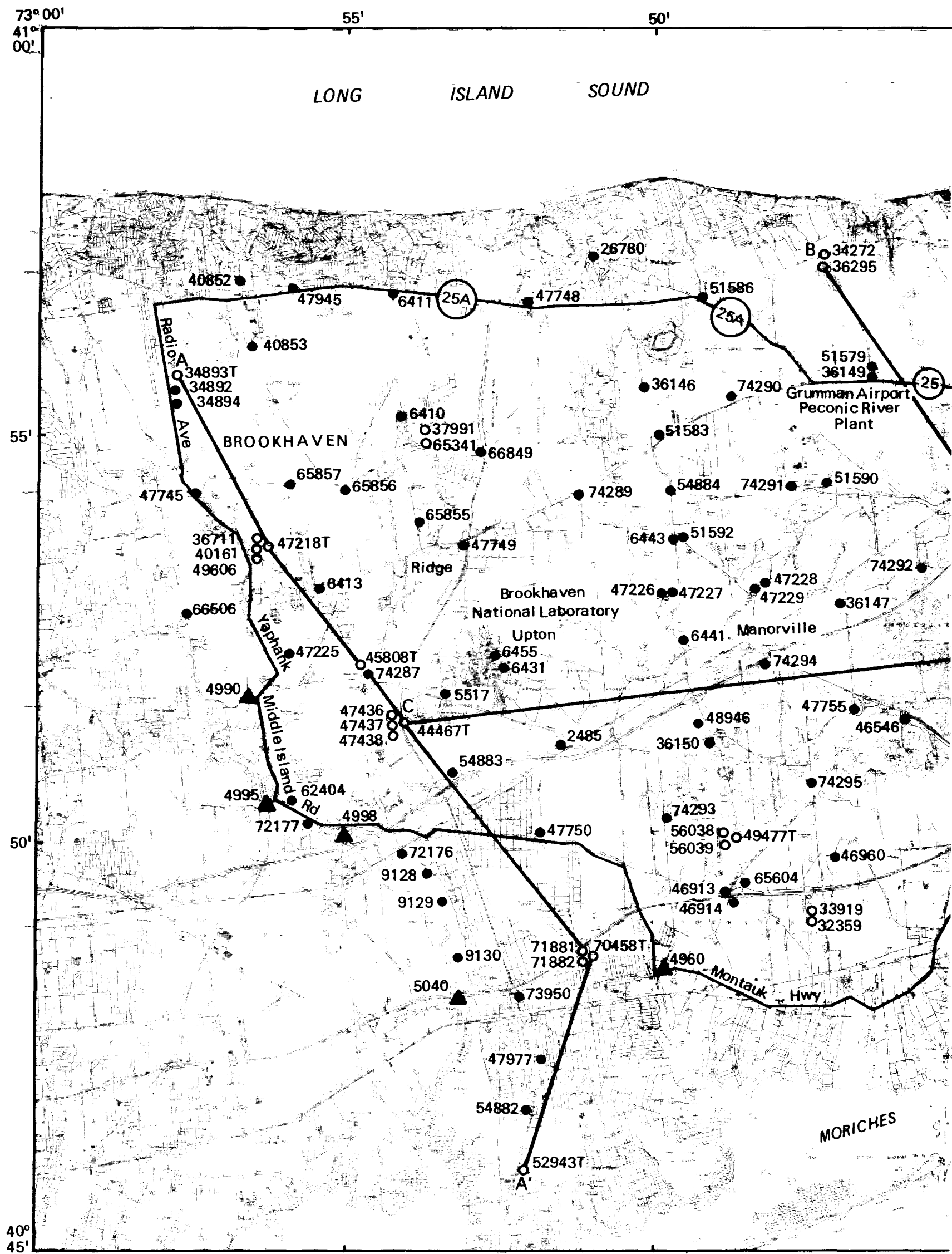

Base from U.S. Geological Survey Topographic maps, 1:24,000 scale

Figure 2.--Location of wells and streamflowand position of geologic 


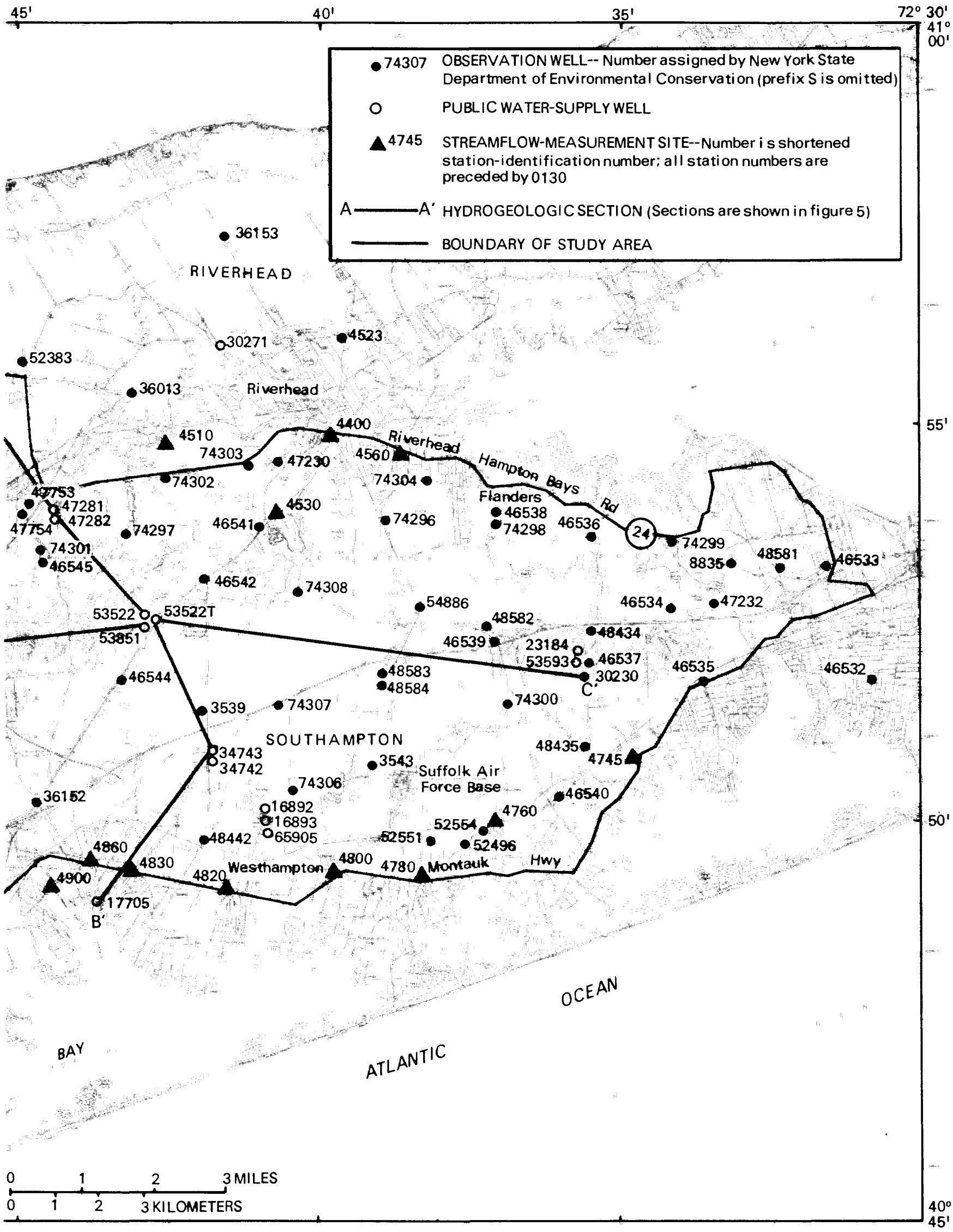

measurement sites in Pine Barrens sections shown in figure 5 . 


\section{GENERAL SETTING}

\section{Location and Extent of Area}

The Long Island Pine Barrens encompass approximately $50 \mathrm{mi}^{2}$ in southeastern Suffolk County between $72^{\circ} 30^{\prime}$ and $72^{\circ} 58^{\prime} \mathrm{W}$ longitude and $40^{\circ} 48^{\prime}$ and $40^{\circ} 57^{\prime} \mathrm{N}$ latitude. A detailed map of the area is shown in figure 2 . The area is bounded on the north by Routes 25 and 25A, on the east by RiverheadHampton Bays Road (Route 24), on the south by Montauk Highway (Route 27A) and Yaphank-Middle Island Road, and on the west by Radio Avenue-Yaphank-Middle Island Road. The area encompasses the southeastern part of the Town of Brookhaven, the southwestern part of the Town of Riverhead, and the western part of the Town of Southampton.

\section{Land Use}

Land in the Pine Barrens is used for several purposes, principally housing, parks and recreation, and agriculture, with smaller allotments for commerce and industry, transportation, and utilities. Residential use predominates in the western part of the Town of Brookhaven and in the southern part of the Town of Southampton along Montauk Highway, whereas recreational and agricultural use predominate in the eastern part of the Town of Brookhaven and the western part of the Town of Southampton. The recreational lands consist of parks and wildlife sanctuaries; the agricultural lands are mainly sod farms, orchards, shrub and tree nurseries, and fields for crops such as corn, cauliflower, cabbage, and potatoes. Commerce and industry are confined to the major roads. The three biggest single occupants are Brookhaven National Laboratories, the Navy Industrial Aircraft facilities, and Suffolk Air Force Base (fig. 2).

\section{Population}

Population of the Pine Barrens area in 1981 is estimated to have been about 23,000 (Long Island Lighting Company, 1981). This figure is based upon the populations of the six main townships in the area--Manorville, 6,820; Riverside-Flanders, 5,400; Westhampton, 1,580; Brookhaven National Laboratory, 400 , and Ridge, 8,830 ( $\mathrm{fig} .2$ ). The figures and estimates do not include the part-time residents and tourists, who substantially increase the total population and water demands during summer. The number of seasonal residents is unknown.

\section{GEOHYDROLOGY}

\section{Geologic Setting}

The Pine Barrens is underlain by unconsolidated deposits that rest unconformably on the Precambrian(?) basement complex (fig. 3). The formations strike northeast and dip to the southeast. Depth to basement increases southward from approximately $900 \mathrm{ft}$ on the north shore to $1,500 \mathrm{ft}$ below sea level on the barrier islands. 
The basement complex is overlain by the Raritan Formation, which consists of the Lloyd Sand Member and an overlying clay member. The Lloyd Sand Member is approximately $300 \mathrm{ft}$ thick, and the clay member is approximately $200 \mathrm{ft}$ thick. The Matawan Group and Magothy Formation, undifferentiated, overlies the Raritan Formation; its thickness ranges from $100 \mathrm{ft}$ at the north shore to more than $900 \mathrm{ft}$ in the southern part of the area. These three units are of Late Cretaceous age and are continuous beneath the study area. The Monmouth Group disconformably overlies the Matawan Group and Magothy Formation, undifferentiated, and is in turn disconformably overlain by the Gardiners Clay. The Monmouth Group is a marine deposit of Cretaceous age that occurs along the barrier islands, primarily in Suffolk County. Its thickness ranges from 0 to $200 \mathrm{ft}$.

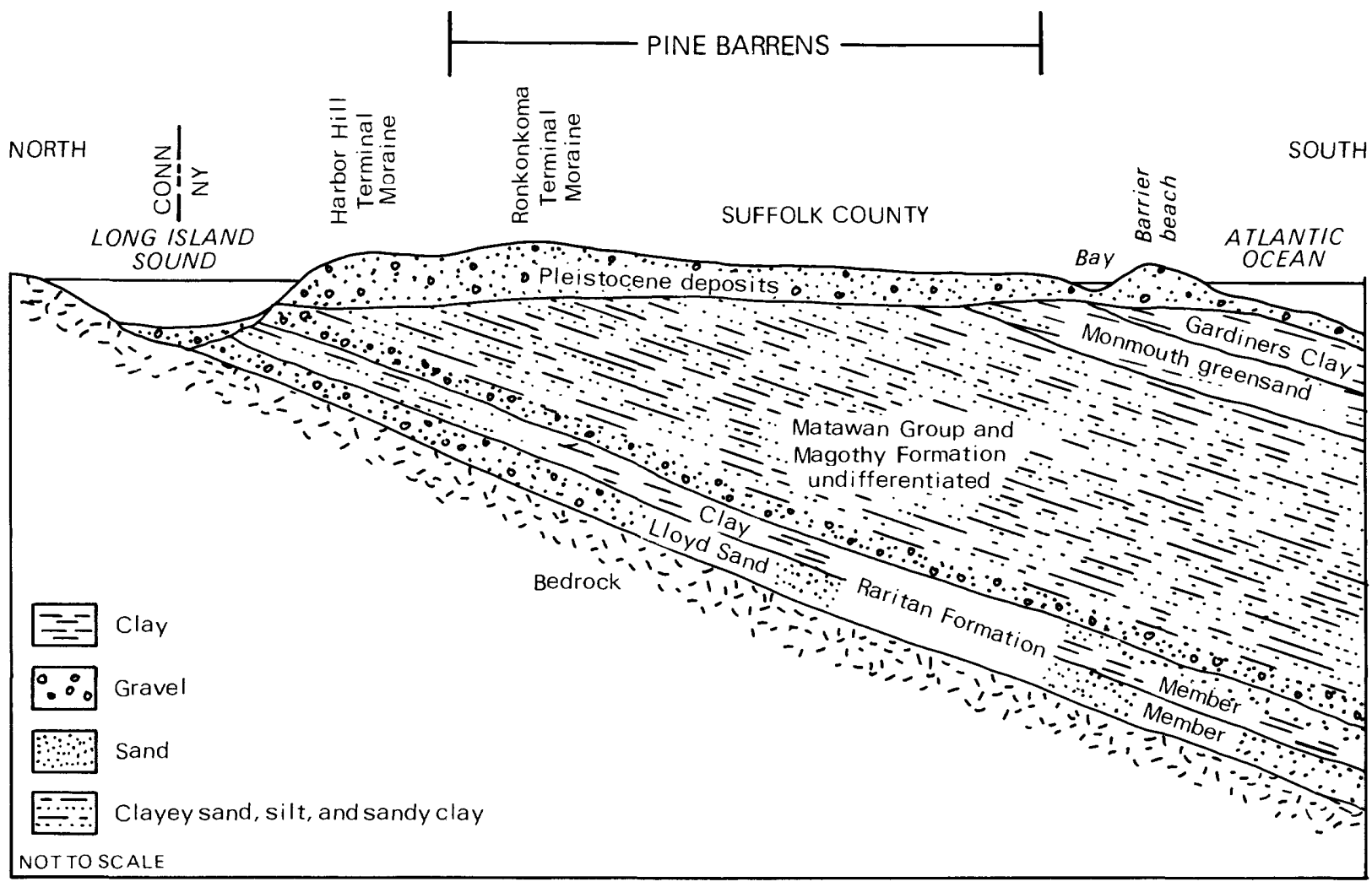

Figure 3.--Generalized geologic section of the Pine Barrens. (Modified from Cohen and others, 1968.)

The altitude of the top of the Matawan Group and Magothy Formation, undifferentiated, is shown in figure 4. Recent test-hole data indicate a buried channel, more than $600 \mathrm{ft}$ below sea level in the northwestern part of the area, that extends north to the limit of the Matawan Group and Magothy Formation, undifferentiated, sequence, as defined by Jensen and Soren (1974). North of this limit it was eroded away by glacial activity, so that subsequent Pleistocene deposits unconformably overlie the Raritan Formation in that area. The channel is bounded on the northeast by a surface high having an altitude of less than $150 \mathrm{ft}$ below sea level. 


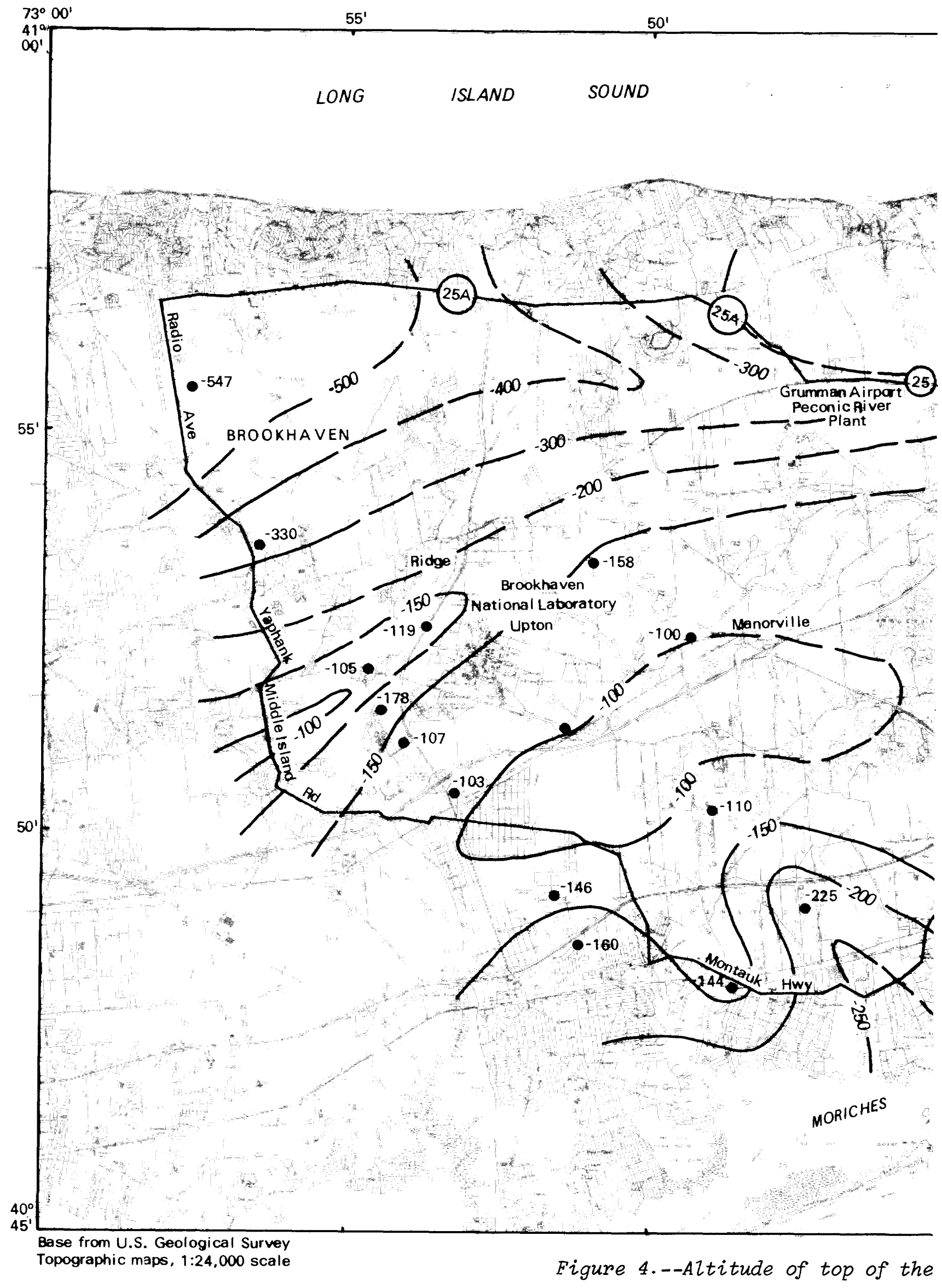




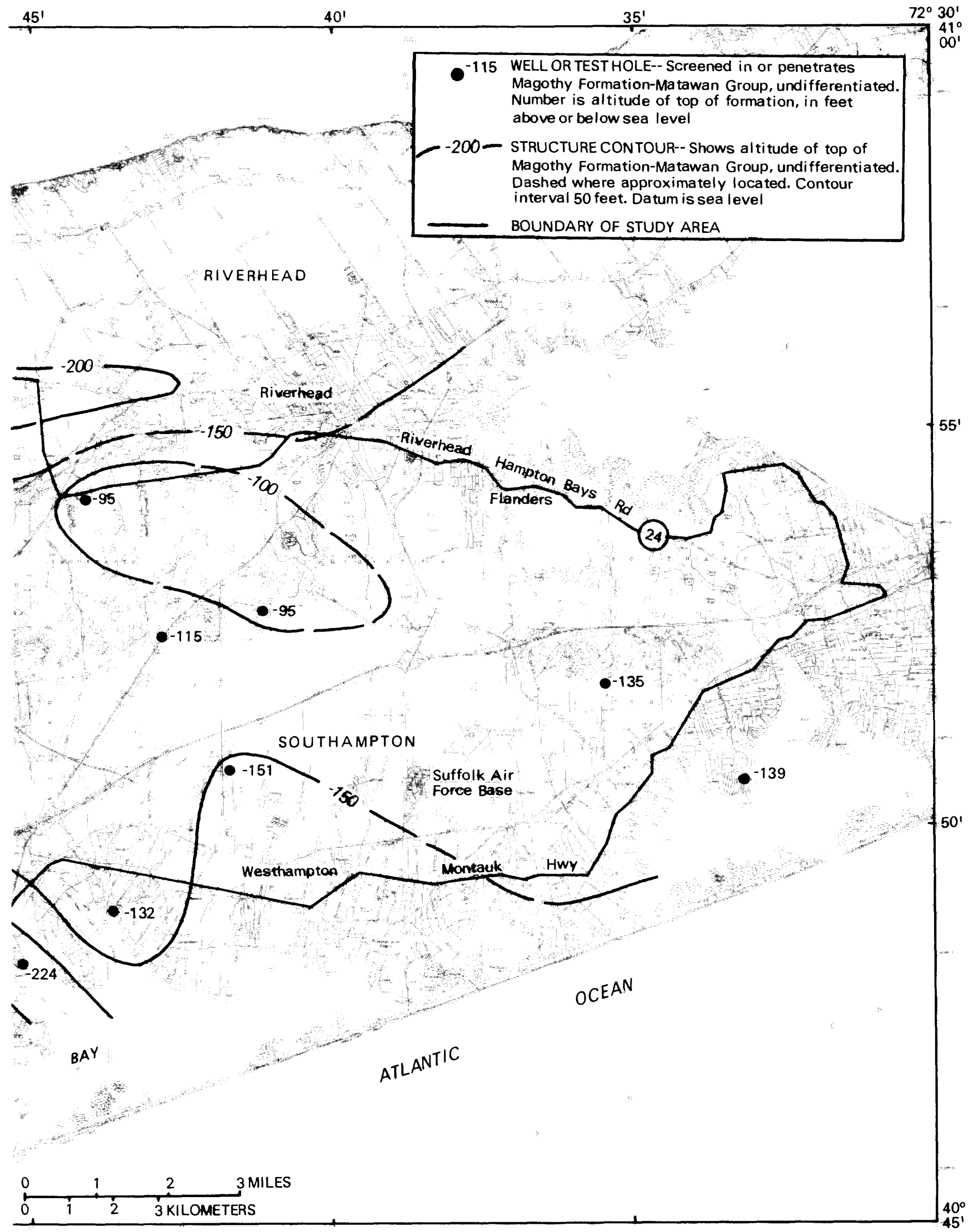

Magothy-Matawan Formation, undifferentiated. 
The Pleistocene formations of the area consist of several glacial, periglacial, and interglacial units, including a marine clay known as the Gardiners(?) Clay. The surficial geologic units consist of Pleistocene outwash, moraines, and Holocene deposits; the Holocene material includes shore, beach, salt-marsh deposits, and, at certain locations, artificial fill. The geologic and corresponding hydrogeologic units in the area are summarized in table 1; three sectional stratigraphic diagrams of several deep test we1ls within the area are given in figure 5.

Table 1.--Geologic and hydrogeologic units in the Pine Barrens. 1

[Relative position of units is shown in fig. 3]

\begin{tabular}{|c|c|c|}
\hline $\begin{array}{l}\text { Hydrogeologic } \\
\text { unit }\end{array}$ & $\begin{array}{c}\text { Geologic } \\
\text { name }\end{array}$ & $\begin{array}{l}\text { Description and } \\
\text { water-bearing character }\end{array}$ \\
\hline $\begin{array}{l}\text { Upper glacial } \\
\text { aquifer }\end{array}$ & $\begin{array}{l}\text { Holocene and } \\
\text { upper Pleistocene } \\
\text { deposits }\end{array}$ & $\begin{array}{l}\text { Mainly brown and gray sand and gravel of } \\
\text { moderate to high hydraulic conductiv- } \\
\text { ity; also includes deposits of clayey } \\
\text { glacial till and lacustrine clay of } \\
\text { low hydraulic conductivity. A major } \\
\text { aquifer. }\end{array}$ \\
\hline $\begin{array}{l}\text { Gardiners } \\
\text { Clay }\end{array}$ & $\begin{array}{l}\text { Gardiners } \\
\text { Clay }\end{array}$ & $\begin{array}{l}\text { Green and gray clay, silt, clayey and } \\
\text { silty sand, and some interbedded } \\
\text { clayey and silty gravel: low hydraulic } \\
\text { conductivity. Unit tends to confine } \\
\text { water in underlying aquifer. }\end{array}$ \\
\hline $\begin{array}{l}\text { Monmouth } \\
\text { greens and }\end{array}$ & $\begin{array}{l}\text { Monmouth Group, } \\
\text { undifferentiated }\end{array}$ & $\begin{array}{l}\text { Interbedded marine deposits of dark- } \\
\text { gray, olive-green, dark-greenish-gray, } \\
\text { and greenish-black glauconitic and } \\
\text { lignitic clay, silt, and clayey and } \\
\text { silty sand. Unit has low hydraulic } \\
\text { conductivity and tends to confine } \\
\text { water in underlying aquifer. The } \\
\text { northern limit of this formation may } \\
\text { lie slightly south of the study area. }\end{array}$ \\
\hline $\begin{array}{l}\text { Magothy } \\
\text { aquifer }\end{array}$ & $\begin{array}{l}\text { Matawan Group and } \\
\text { Magothy Formation, } \\
\text { undifferentiated }\end{array}$ & $\begin{array}{l}\text { Gray and white fine to coarse sand of } \\
\text { moderate hydraulic conductivity. } \\
\text { Generally contains sand and gravel } \\
\text { beds of low to high hydraulic } \\
\text { conductivity in basal } 100 \text { to } 200 \text { feet. } \\
\text { Contains much interstitial clay and } \\
\text { silt, and beds and lenses of clay of } \\
\text { low hydraulic conductivity. A major } \\
\text { aquifer though not highly developed in } \\
\text { the study area. }\end{array}$ \\
\hline $\begin{array}{l}\text { Raritan } \\
\quad \text { Clay }\end{array}$ & $\begin{array}{l}\text { Unnamed clay member } \\
\text { of the Raritan } \\
\text { Formation }\end{array}$ & $\begin{array}{l}\text { Gray, black, and multicolored clay and } \\
\text { some silt and fine sand. Unit has low } \\
\text { hydraulic conductivity and tends to } \\
\text { confine water in underlying aquifer. }\end{array}$ \\
\hline $\begin{array}{l}\text { Lloyd } \\
\quad \text { aquifer }\end{array}$ & $\begin{array}{l}\text { Lloyd Sand Member } \\
\text { of the Raritan } \\
\text { Formation }\end{array}$ & $\begin{array}{l}\text { White and gray fine-to-coarse sand and } \\
\text { gravel of moderate hydraulic conduc- } \\
\text { tivity and some clayey beds of low } \\
\text { hydraulic conductivity. Not developed } \\
\text { as a source of water in the study } \\
\text { area. }\end{array}$ \\
\hline Bed rock & $\begin{array}{l}\text { Undifferentiated } \\
\text { crystalline } \\
\text { rocks }\end{array}$ & $\begin{array}{l}\text { Mainly metamorphic rocks of low hydrau- } \\
\text { lic conductivity: surface generally } \\
\text { weathered: considered to be the bottom } \\
\text { of the ground-water reservoir. }\end{array}$ \\
\hline
\end{tabular}

1 Modified from Jensen and Soren (1971). 

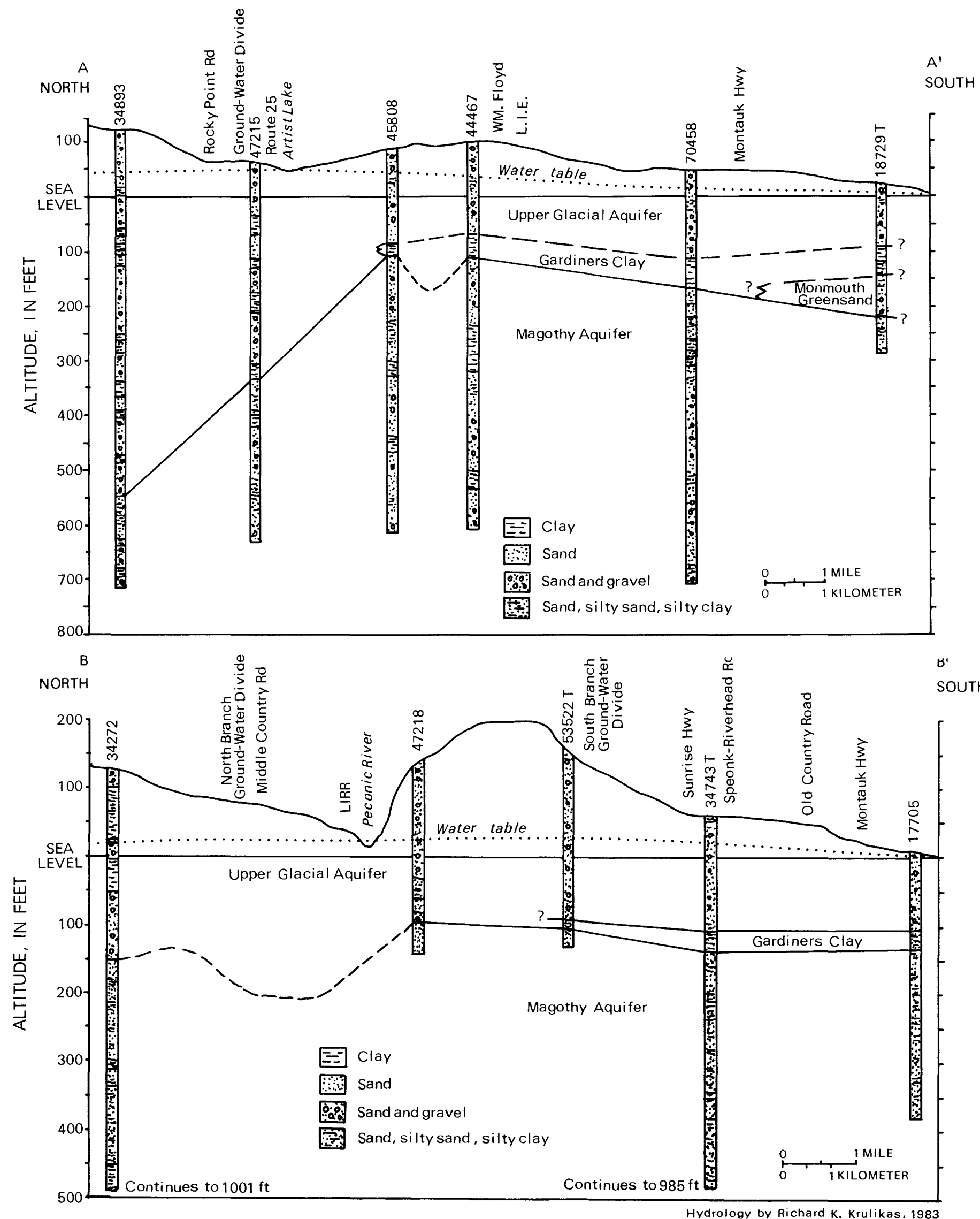

Figure 5.--Geohydrologic sections $A-A^{\prime}$ and $B-B^{\prime}$ in the Pine Barrens of Suffolk County. (Locations of sections are shown in fig. 2.) 


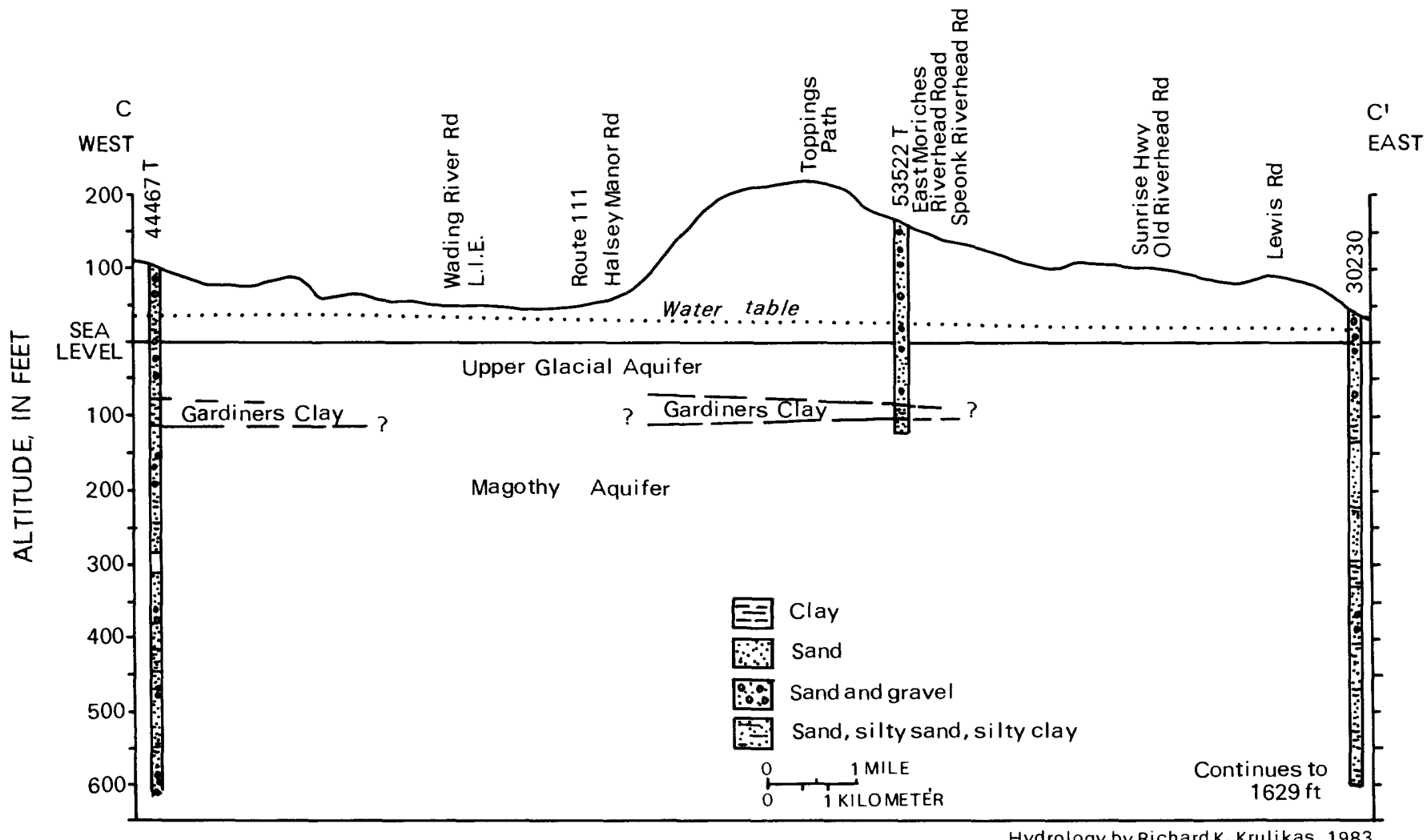

Figure 5.--Geohydrologic sections $A-A^{\prime}$ and $B-B^{\prime}$ in the Pine Barrens of Suffolk County. (Locations of sections are shown in fig. 2.)

\section{Hydrology}

Precipitation is the sole source of freshwater in the Pine Barrens, and recharge to the ground-water reservoir results from infiltration of precipitation through the soil to the water table. The amount of water that reaches the water table varies throughout the year and is controlled by (1) form, frequency, and intensity of precipitation; (2) slope of the land surface; (3) geology, soil-moisture content, and the amount and kind of vegetal cover; and (4) air temperature.

\section{Precipitation}

The climate of the Pine Barrens is characterized by a moderate temperature range and mild winters that are influenced by the Atlantic Ocean and Long Island Sound. Precipitation falls in almost the same total amount in the cool season as during the warm season but is more frequent in spring than in fall. Most precipitation on Long Island is in the form of rain; only 5 to 10 percent falls as snow or sleet. Long-term precipitation in Suffolk County averages $43 \mathrm{in} / \mathrm{yr}$, as determined from 30 years of records collected by the National Weather Service. 
The precipitation regime of Long Island during 1951-65 was studied by Miller and Frederick (1969), who calculated the mean annual precipitation for the Pine Barrens area to be between 44 and 46 inches. This compares closely with the $43 \mathrm{in} / \mathrm{yr}$ for all of Suffolk County. The annual precipitation recorded at Upton (fig. 1) during 1943-82 had a maximum of 58.63 inches in 1972 and a minimum of 31.82 inches in 1965 (fig. 6A); the long-term average annual precipitation from $1943-82$ is 46.32 inches. Mean monthly precipitation at Upton ranges from a low of 3.12 inches in June to a high of 4.60 in December (fig. 6B).

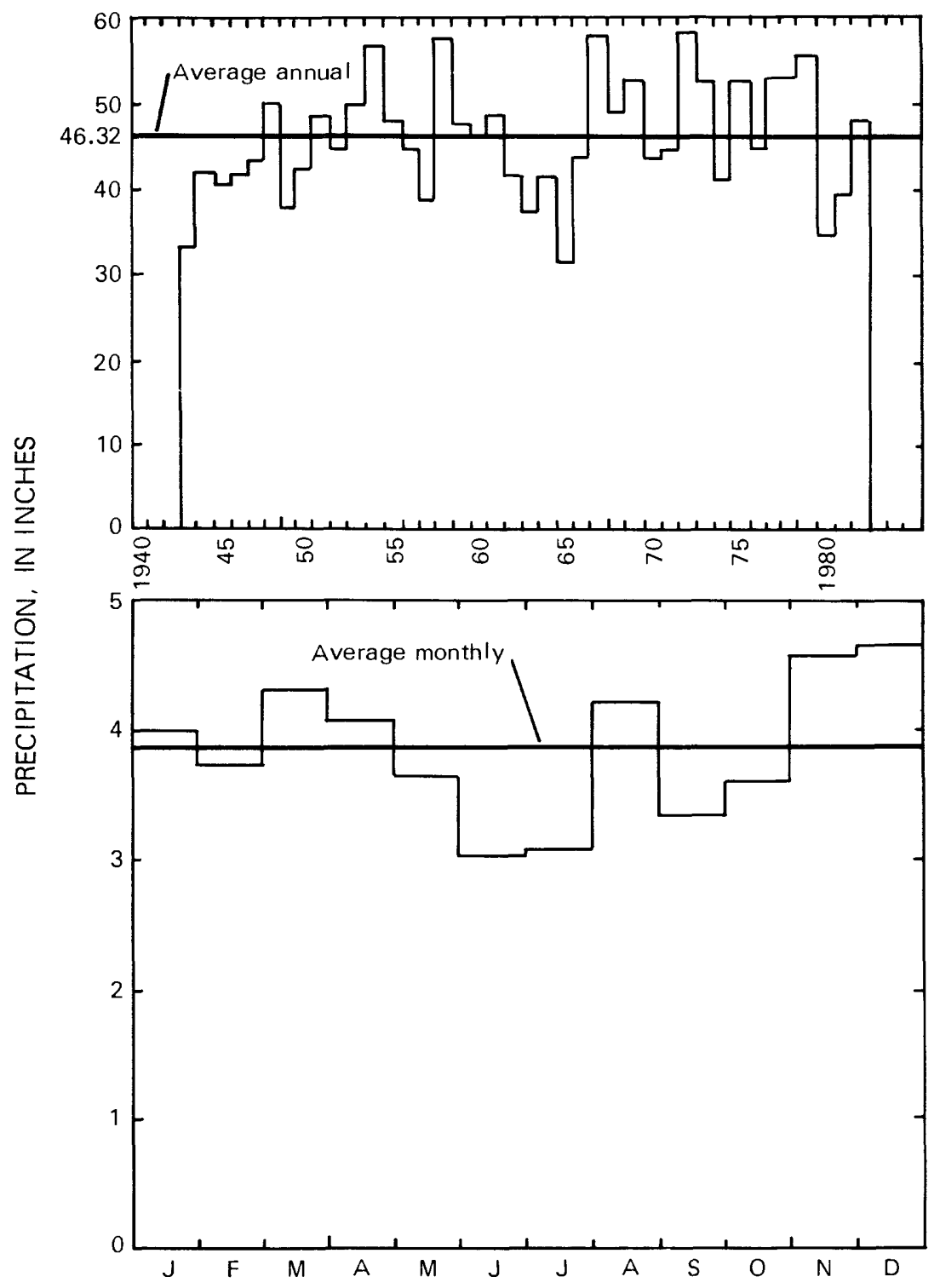

Figure 6.--Average annual and average monthly precipitation at Upton, Suffolk County, 1943-82. 


\section{Recharge and Discharge of Ground Water}

Ground water in the Pine Barrens is recharged by infiltration of precipitation through the surficial deposits to the water table. The quantity of water that reaches the water table varies throughout the year. Several factors control the amount of recharge; these include variations in precipitation, the stratigraphy and soil characteristics of the area, and the rate of evapotranspiration (the natural loss of water through both evaporation and transpiration by plants).

Evapotranspiration was not measured directly in this study; therefore, all calculations must be considered estimates. An accepted estimate of annual evapotranspiration on Long Island is 23.2 inches, as calculated by Bart and others (1976, p. E24) from the Thornthwaite water-balance calculations for mean weather data. Average values for precipitation, evapotranspiration, and overland runoff can be used in equation 1 to calculate average recharge:

$$
\text { Recharge }=\text { precipitation - (evapotranspiration + overland runoff) }
$$

From an average annual precipitation value of 46.3 inches, an estimated average annual evapotranspiration rate of 23.2 inches, and an average overland runoff value of 0.5 inches, recharge becomes:

$$
\text { Recharge }=46.3-(23.2+0.5)=22.6 \mathrm{in} / \mathrm{yr}
$$

This value of $22.6 \mathrm{in} / \mathrm{yr}$ should be considered only as a rough approximation, however, because rates of recharge, precipitation, evapotranspiration, and other factors may vary considerably from place to place and with time.

Ground water is discharged naturally as seepage to streams along both the north and south shores of the study area and also into the Carmans and Peconic River basins (fig. 2). Ground water also discharges directly into the bays along the shore. This is apparent along the south shore, where the potentiometric heads in the Magothy aquifer (well S32359) are greater than or equal to the potentiometric heads in the upper glacial aquifer (we11 S33919), as shown by the water-1evel maps in figure 8 (p. 20) and 9 (p. 22).

\section{Flow Subsystems and Recharge Zones}

Under natural conditions, the only source of water to the Long Island ground-water system is recharge from precipitation. Approximately half the precipitation that reaches the land surface infiltrates and enters the groundwater system at the water table. Some of this water flows in a shallow flow subsystem and discharges to streams or lakes. Water that enters the system near the shore flows through the upper glacial aquifer and discharges to the sea; water that enters the system further inland flows down to the deeper aquifers. Water near the major ground-water divide (fig. 7, p. 16), flows downward to the Lloyd aquifer. 
Overlying the deep flow system on each side of the major ground-water divide is a series of shallow subsystems, each of which converges laterally toward a stream and eventually discharges to the bays and ocean.

The recharge zone for the deep subsystem is an area in which water entering the ground-water system flows down into the deep aquifers (Magothy and Lloyd aquifers). Knowledge of the location and extent of these areas is needed by managers responsible for water development because the deep aquifers are considered potential sources of potable water for Suffolk County. Proper management of development in such areas is essential to prevent human-induced contamination from reaching these deep aquifers and to thereby maintain potable water supplies in the Pine Barrens.

The exact locations of the deep recharge zones in the Pine Barrens are unknown but can be inferred to a degree from the flow patterns within the shallow-flow subsystems. The boundary separating the deep regional flow system from the shallow systems intersects land surface in an east-westtrending line somewhere seaward of the major ground-water divide but north of the start of streamflow (start-of-flow point), as shown in figure 7. A transition zone separates the deep and shallow flow systems, but to locate it accurately would require detailed data on the three-dimensional distribution of heads and seasonal variations in head in the ground-water system. An approximate delineation of this transition zone based on the start-of-flow points of each stream in the area is shown in figure 7. The position and configuration of this transition zone changes as the ground-water system responds to seasonal and induced stresses.

The ground-water-contributing area around the upper reaches of the Peconic River is difficult to delineate because this area has poor drainage and many small ponds and swamps, and thus contributes little base flow to the Peconic River. Discharge in the upper reaches averaged $3 \mathrm{ft}^{3} / \mathrm{s}$; that in the downstream reaches averages $30 \mathrm{ft}^{3} / \mathrm{s}$ (Warren and others, 1968). It is therefore probable that the main ground-water contributing area is around the downstream reaches of the Peconic River.

\section{Ground-Water Levels}

Long Island's major ground-water divide, which traverses the island from west to east, passes through the Pine Barrens and splits near Riverhead into a north branch extending into the north fork and a south branch extending into the south fork (fig. 9, p. 20). Ground water north of the divide moves northward to Long Island Sound, and ground water south of the divide moves southward to Great South Bay and Moriches Bay, either directly or by way of streams. In general, ground water from the area between the two branches of the divide moves eastward to the Peconic River and Peconic Bay. This divide is not stationary but moves north or south as the water-table configuration changes. These changes occur seasonally and also during periods of recharge or drought. Seasonal fluctuations in water levels at the divide are usually less than $5 \mathrm{ft}$. 


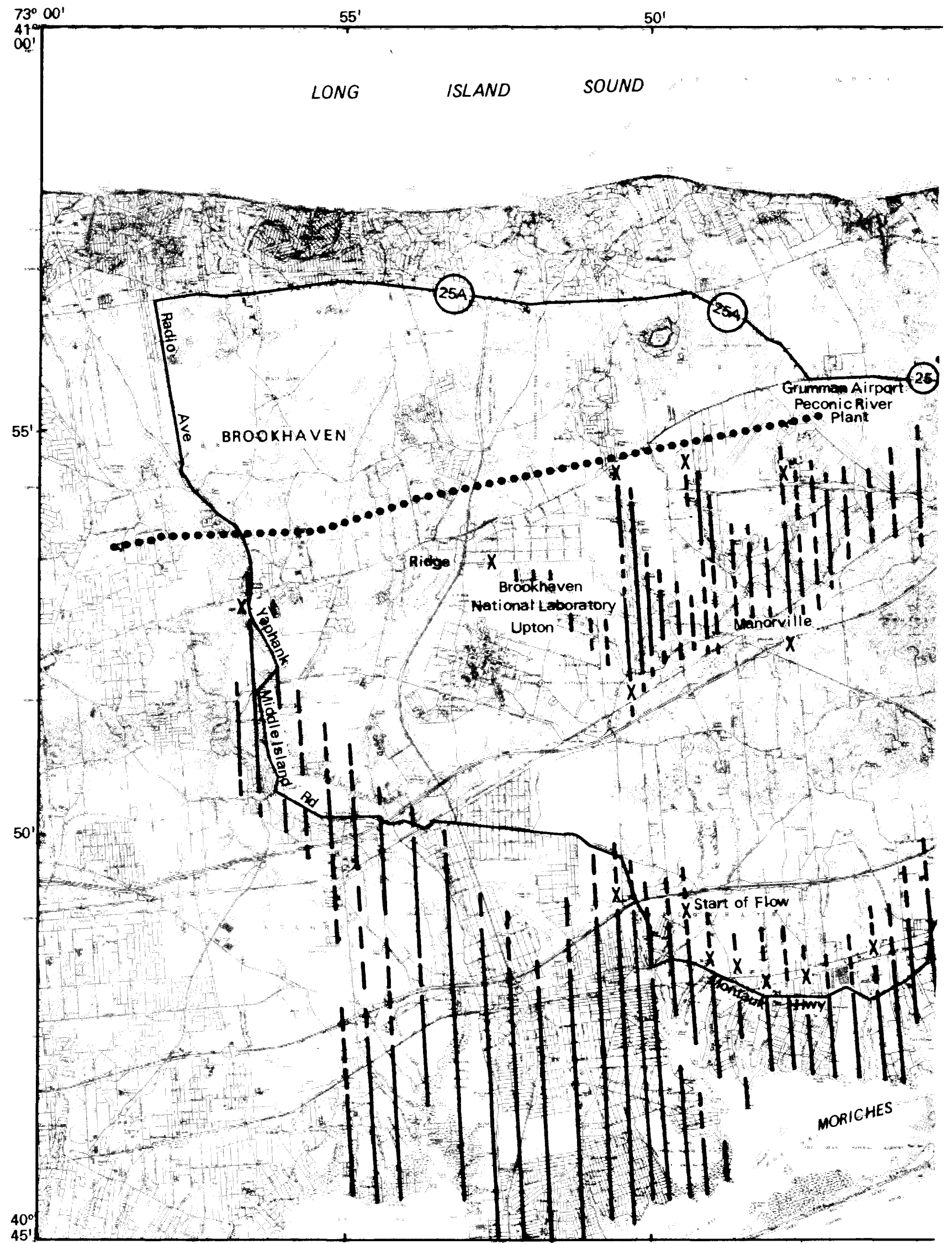

Base from U.S. Geological Survey

Topographic maps, 1:24,000 scale

Figure 7.--Approximate areas of shallow and 


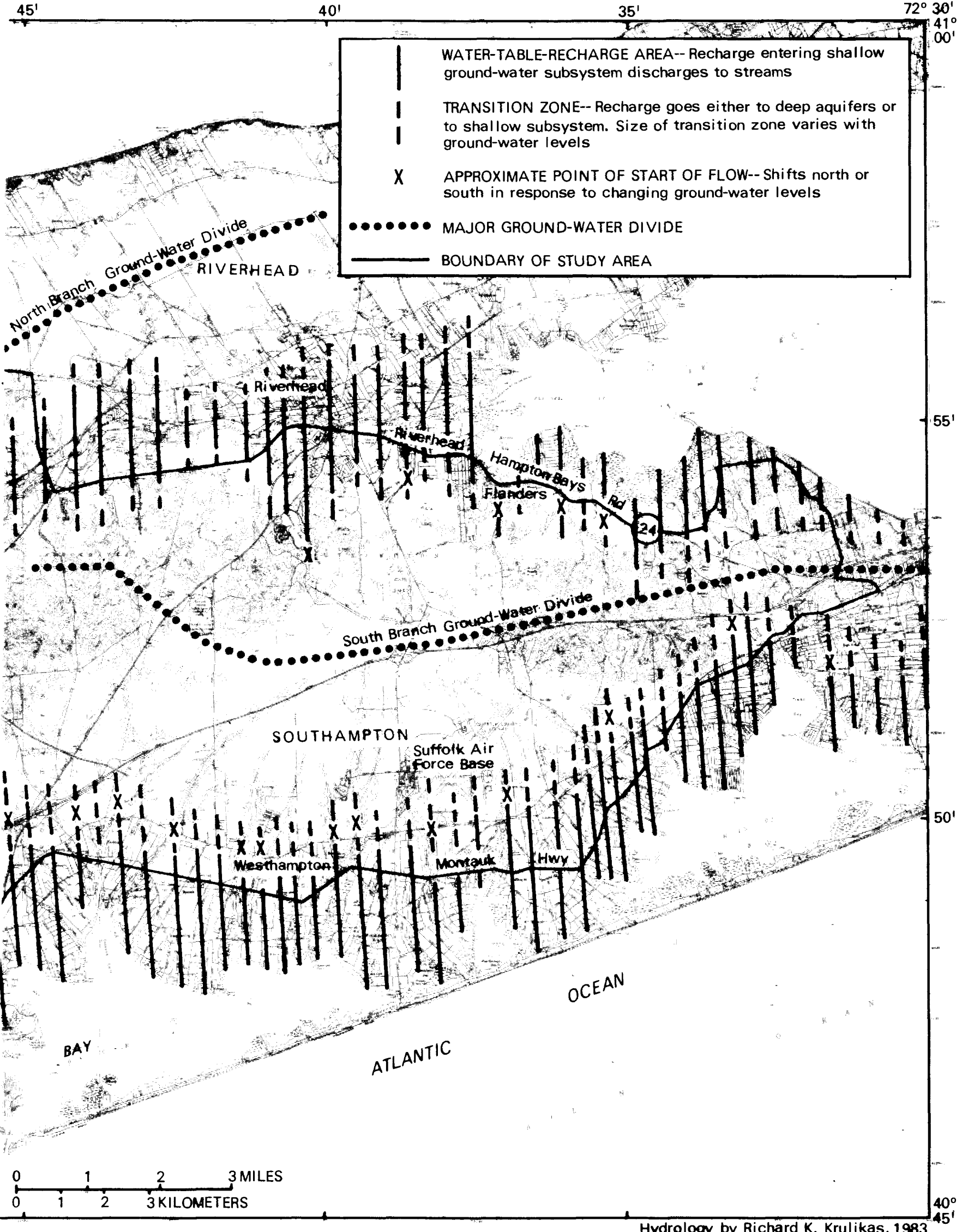

deep ground-water flow subsystems. 
Water table.--Water-1eve1 measurements were made in 112 observation we11s during June 1983 (see table 8, at end of report) and were used to prepare a water-table map of the Pine Barrens (fig. 9). The water-table altitude reaches a maximum of $55 \mathrm{ft}$ above sea level in the northwest part of the Pine Barrens and decreases to $5 \mathrm{ft}$ in the eastern part. The lower water-table altitude in the east is a result of ground-water discharge into the Peconic River basin and Shinnecock Bay.

The U.S. Geological Survey has monitored water levels in several observation wells in the Pine Barrens since the early 1940's. Figure 8 depicts 1958-82 hydrographs for four of the we11s. The water levels coincide in terms of periodicity of water-level fluctuations but differ in magnitude of change.

Magothy aquifer.--Water levels in the Magothy aquifer were measured at five we11s in June 1983; these data were used to prepare a potentiometricsurface map of the Magothy aquifer (fig. 10). (The potentiometric surface represents the static head, which is defined by the levels to which water would rise in a tightly cased well screened at a specific depth.) The potentiometric-surface altitude of the Magothy aquifer reaches a maximum of about $47 \mathrm{ft}$ above sea level in the western part of the study area and decreases to zero eastward as it approaches the shore. Where data are lacking, the contours are inferred.

\section{Surface Water}

One of the 11 streams within the Pine Barrens flows northward into Peconic Bay; the other 10 flow southward into Moriches Bay or Shinnecock Bay (fig. 2). The area also contains several natural lakes and ponds; many are kettleholes that intersect the water table, and some are perched. In addition, several ponds have been created behind small dams on some tributaries.

Stream-discharge measurements are made periodically at 17 sites in the area under base-flow conditions as a measure of ground-water seepage to the streams. The locations of these sites are shown in figure 2; the discharge measurements for fal1 1982 and spring 1983 are given in table 9 (at end of report). The U.S. Geological Survey maintains continuous gaging stations on the Peconic and Carmans Rivers. Daily discharges at these sites from 1942 to the present are available at the U.S. Geological Survey's Long Island office in Syosset. 

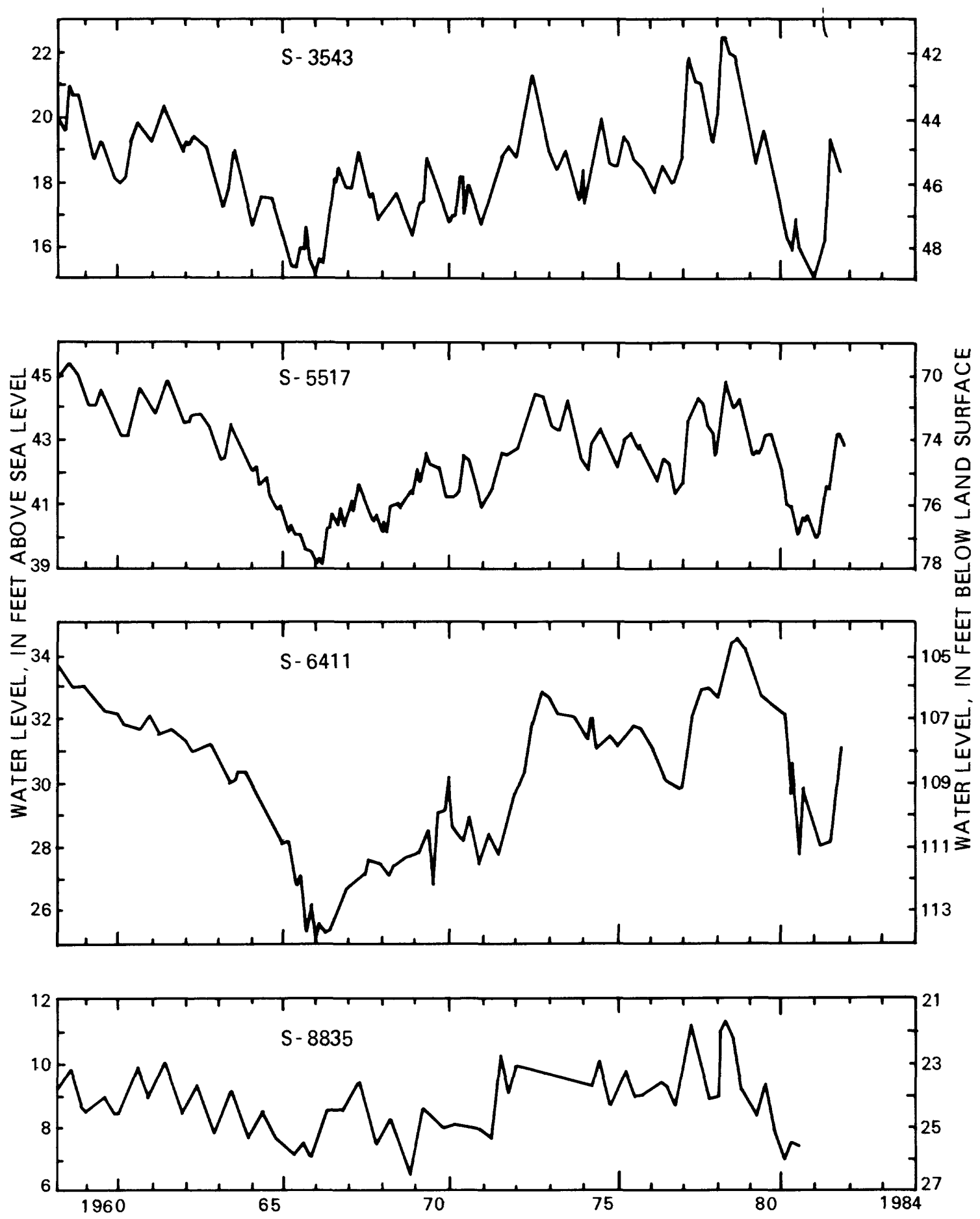

Figure 8.--Long-term (1958-82) hydrographs for wells S3543, S5517, S6411, and S8835. (Locations are shown in fig. 2.) 


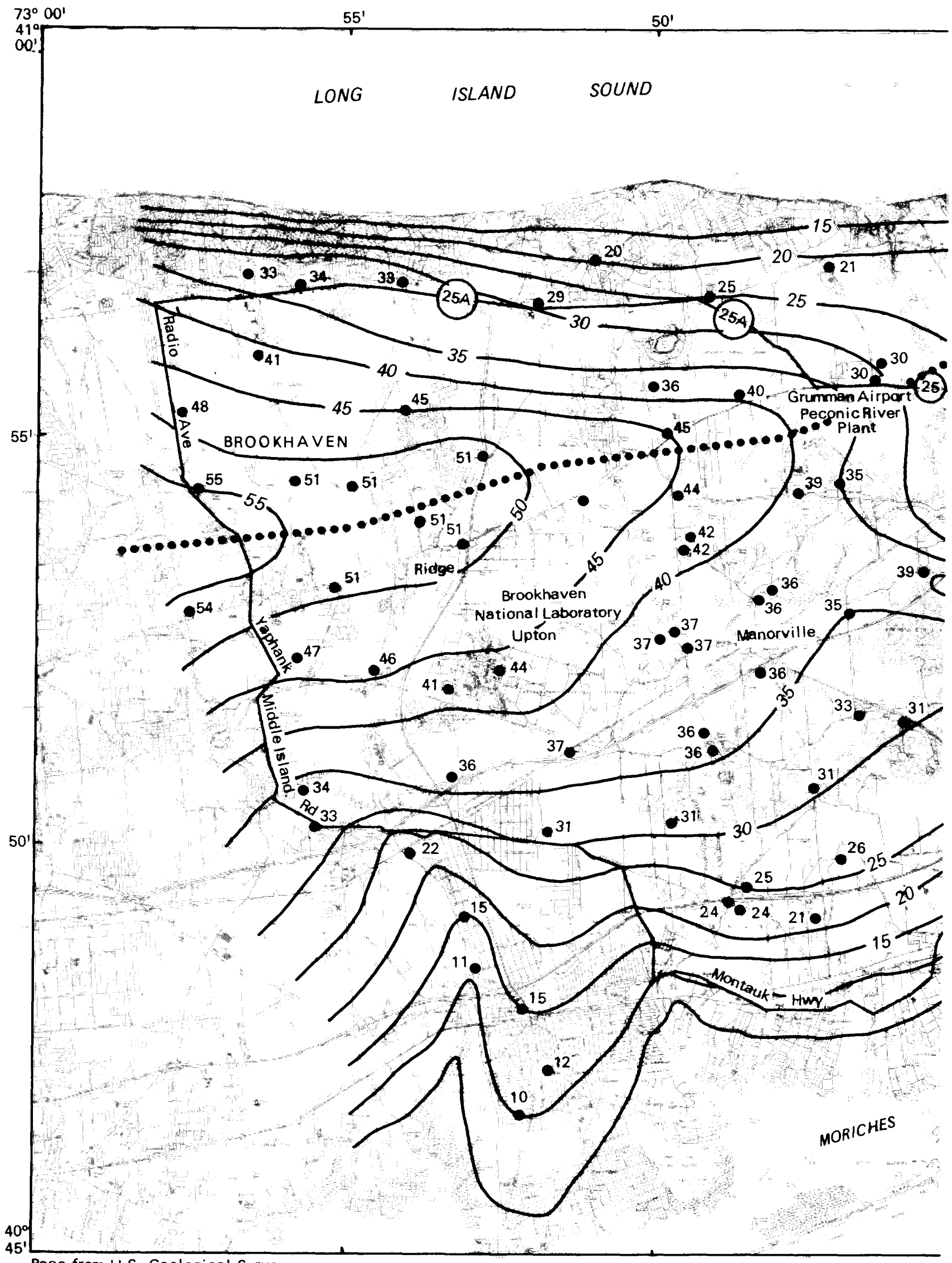

Base from U.S. Geological Survey

Topographic maps, 1:24,000 scale

Figure 9 -Water-table altitude in the 


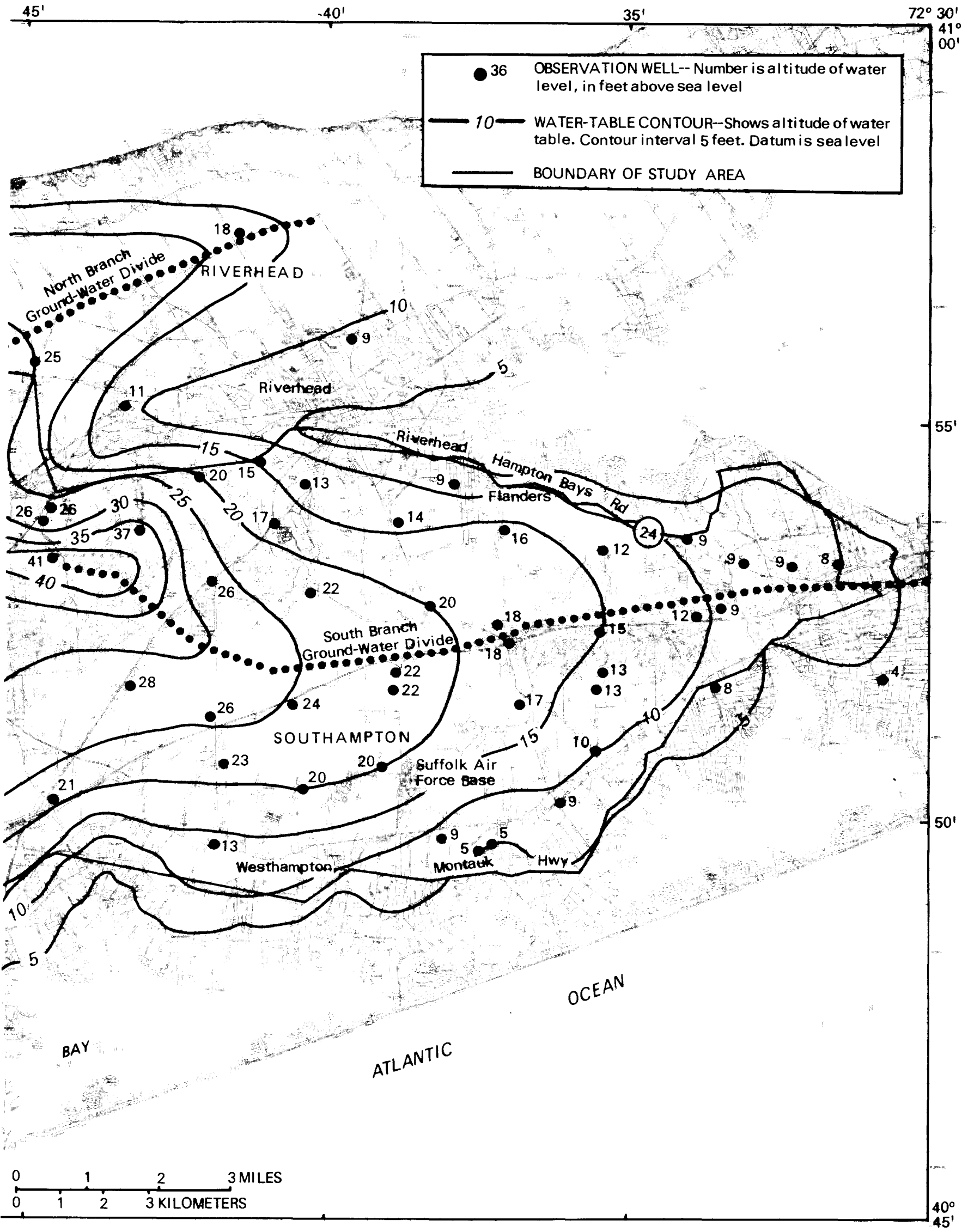

Pine Barrens, September 1983. 


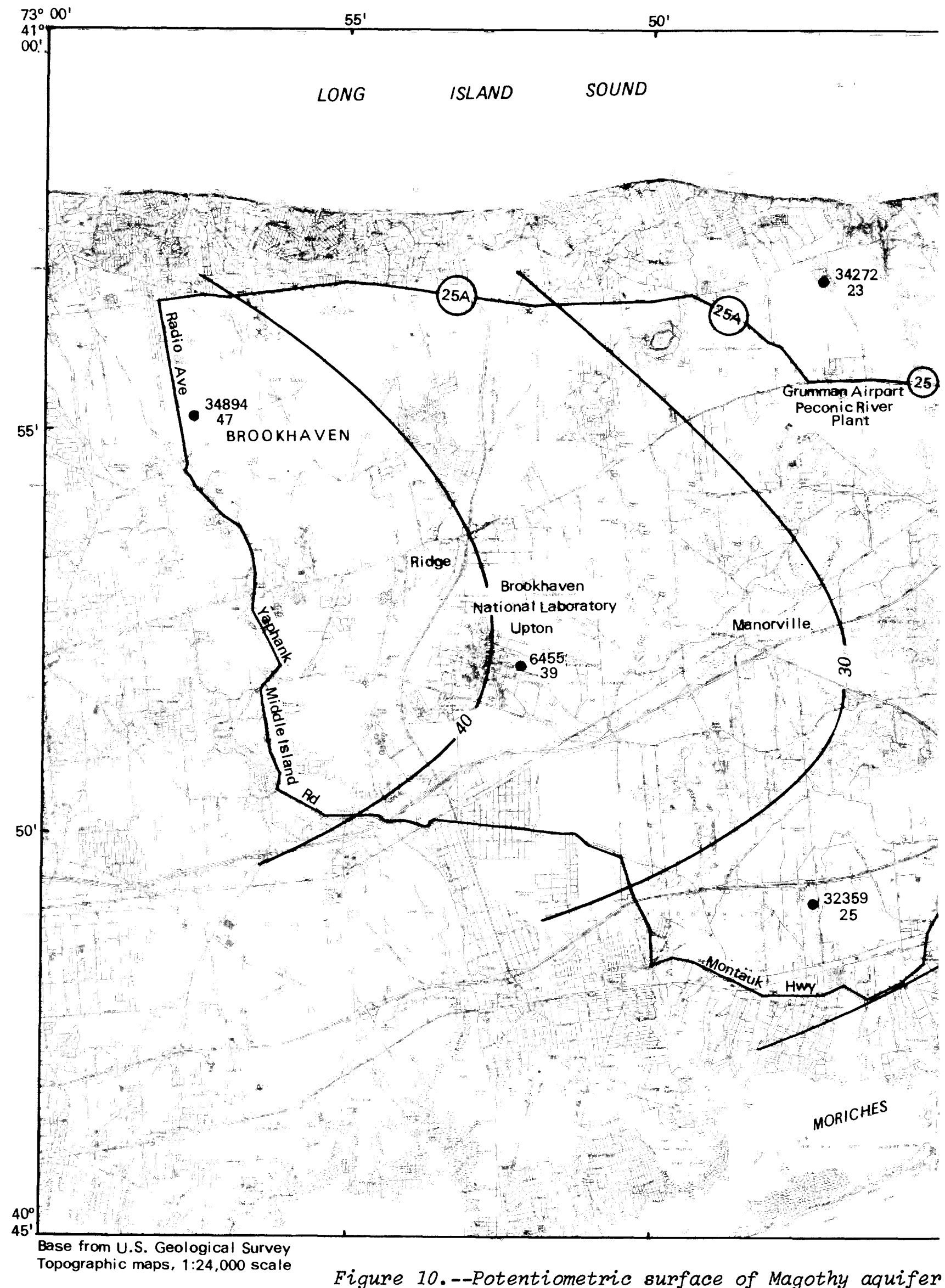

Figure 10.--Potentiometric surface of Magothy aquifer 


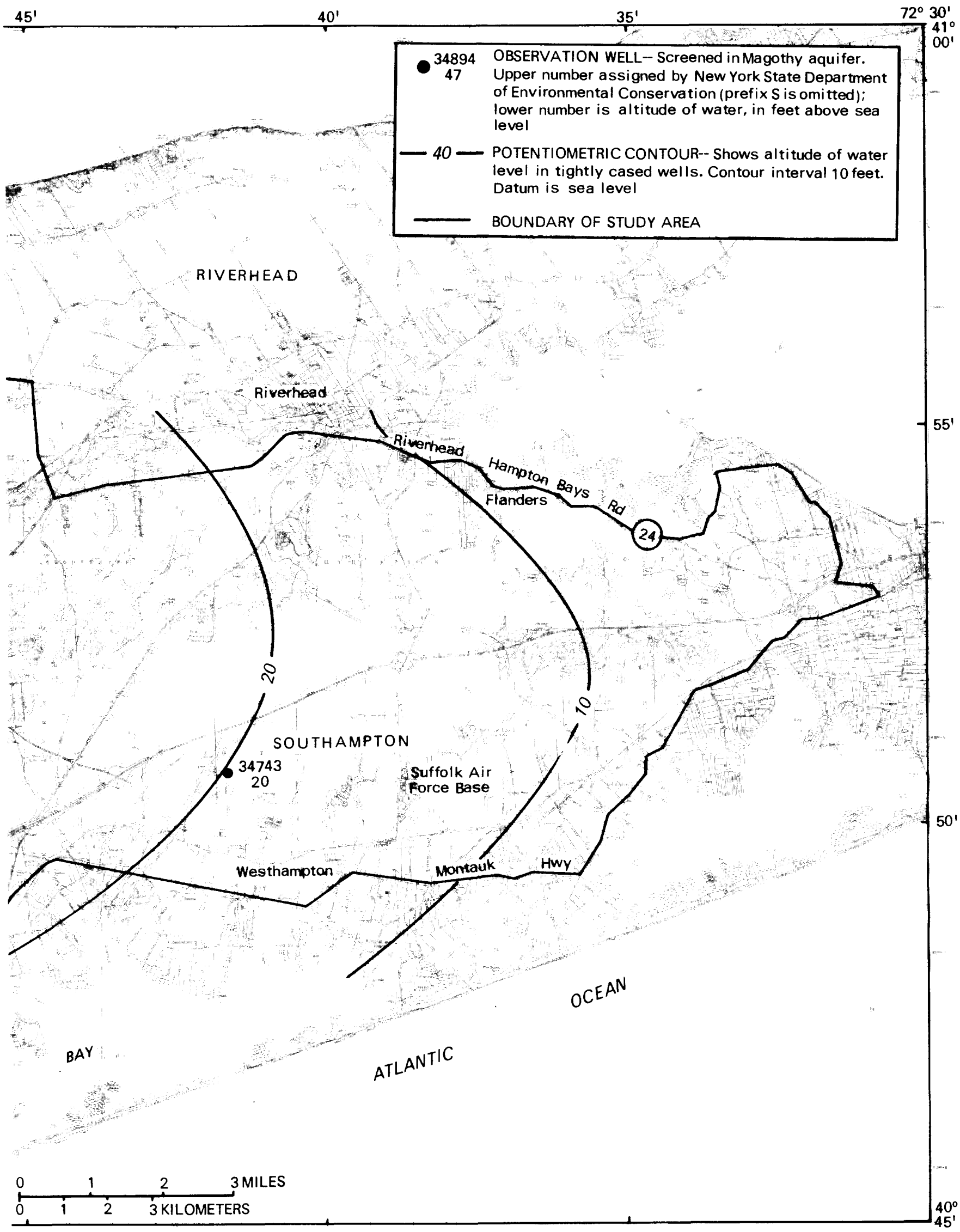

in the Pine Barrens, September, 1983. 


\section{WATER QUALITY}

The chemical quality of water determines the purposes for which the water may be used, such as for drinking, agriculture, or industry. The chemical composition of the water is determined by the type and solubility of material with which the water comes in contact, the duration of contact, the chemical quality of precipitation and the air through which it falls, the water temperature and pressure, and the composition of surface-derived substances such as domestic wastes, fertilizers, and industrial discharges.

\section{Public-Supply Wells}

Chemical analyses of water from public-supply wells sampled by the Suffolk County Department of Health Services in 1980 revealed that no we11s within the Pine Barrens exceeded the drinking-water standard of $10 \mathrm{mg} / \mathrm{L}$ for nitrate-nitrogen nor the $50-\mu \mathrm{g} / \mathrm{L}$ guideline for any single volatile organic compound, as set by the U.S. Public Health Service (U.S. Department of Health, Education, and Welfare, 1962, p. 7).

\section{Observation Wells}

The upper glacial aquifer underlying the Pine Barrens has been monitored by the Suffolk County Department of Health Services for several years at 40 observation wells that are part of the observation-we1l network within Suffolk County (fig. 2). Observation wells are installed by the Suffolk County Department of Health Services to monitor a variety of conditions, including ground-water levels, ambient water quality, presence of cesspool or sewagetreatment-plant effluent, and also for special studies relating to such aspects as streamflow augmentation, landfill leachate, and fuel spills.

A survey of the computer files of the Suffolk County Department of Health Services, which include 1973-83 data on 40 wells, indicated that four of the wells had nitrate-nitrogen concentrations exceeding the $10.0-\mathrm{mg} / \mathrm{L}$ limit set by the U.S. Public Health Service (U.S. Department of Health, Education, and Welfare, 1962, p. 7.) (See table 10, at end of report). Water from two wells exceeded the $50-\mu \mathrm{g} / \mathrm{L}$ guideline for volatile organic chemicals. One of the wells, S45724, is a sewage-treatment-plant monitoring well at Smith Road in Ridge (fig. 11); when sampled on October 18, 1980, it contained $330 \mathrm{\mu g} / \mathrm{L}$ of chloroform (trichloromethane). The other we11, S51591, south of the Navy Industrial Aircraft Facility in Calverton, was sampled on October 29, 1980, and found to contain $120 \mathrm{\mu g} / \mathrm{L}$ of $1,1,1$-trichloromethane.

\section{Private Wells}

Data from the Suffolk County Department of Health Services on private we11s in the Pine Barrens area from January 1978 through March 1981 revealed 13 wells having nitrate-nitrogen concentrations in excess of $10 \mathrm{mg} / \mathrm{L}$ and $\mathrm{six}$ wells with volatile organic chemical concentrations in excess of the $50-\mu \mathrm{g} / \mathrm{L}$ guideline for any single constituent. (Locations of these 19 wells are shown in fig. 11.) The locations, dates, and concentrations at which these contaminants were detected are summarized in table 2. 
A special sampling survey by Suffolk County Department of Health Services for radioactive contamination in private wells was done at the area southeast of Brookhaven National Laboratory. One sample from a private well had 4,100 pci/L of tritium and $0.55 \mathrm{pci} / \mathrm{L}$ of strontium 90 .

Table 2.--Nitrate-nitrogen concentrations greater than $10 \mathrm{mg} / \mathrm{L}$, and volatile organic chemical concentrations greater than $50 \mathrm{\mu g} / \mathrm{L}$ in water samples from selected wells in the Pine Barrens, 1978-82.

[We11 locations are shown in fig. 11]

\begin{tabular}{lcc}
\hline \multicolumn{1}{c}{ A. NITRATE-NITROGEN } & $\begin{array}{c}\text { Concentration } \\
\text { Location }\end{array}$ & Date \\
\hline 1. Main Street, Yaphank & $4-28-80$ & 13.8 \\
2. Tarki11 Road, Ridge & $3-3-80$ & 13.6 \\
3. Nesaquake Terrace, Ridge & $6-27-78$ & 14.2 \\
4. Toppings Path, Calverton & $8-21-79$ & 13.6 \\
5. Lakeside Trail, Ridge & $3-10-81$ & 14.0 \\
6. Wauwepex Trail, Ridge & $6-21-82$ & 11.4 \\
7. Corchaug Trail, Ridge & $6-21-82$ & 10.8 \\
8. Ridge Post Office, Ridge & $6-21-82$ & 14.2 \\
9. Wading River Road, Manorville & $3-4-81$ & 16.0 \\
10. Silas Charter Road, Manorville & $9-14-82$ & 15.0 \\
11. Moriches-Yaphank Road, Manorville & $3-9-82$ & 20.0 \\
12. Orchard Street, Manorville & $6-24-82$ & 10.0 \\
13. South Manor School, South St., Manorville & $1-13-82$ & 10.0
\end{tabular}

B. ORGANIC COMPOUNDS

\begin{tabular}{|c|c|c|c|}
\hline Location & Date & Name & $\begin{array}{c}\text { Concentration } \\
(\mu \mathrm{g} / \mathrm{L})\end{array}$ \\
\hline \multirow[t]{3}{*}{ Route 25, Ridge } & $10-9-79$ & Carbon tetrachloride & 323 \\
\hline & $10-9-79$ & Trichloroethylene & 322 \\
\hline & $10-9-79$ & $1,1,1$-Trichloroethane & 213 \\
\hline $\begin{array}{l}\text { Panamoka Trail, Lake } \\
\text { Panamoka }\end{array}$ & $9-10-79$ & $1,1,1-\operatorname{Trich} 1$ oroethane & 82 \\
\hline Ruth Lane, Ridge & $7-22-80$ & $\begin{array}{l}\text { 0-Xylene } \\
\text { Benzene* }\end{array}$ & $\begin{array}{r}45 \\
441\end{array}$ \\
\hline Rustic Road, Yaphank & $10-2-79$ & Benzene & 726 \\
\hline Randall Road, Ridge & $10-25-82$ & Chloroform & 91 \\
\hline \multirow[t]{5}{*}{ Ryerson Ave., Manorville } & $10-21-81$ & Benzene & 22 \\
\hline & $10-21-81$ & Toluene & 12 \\
\hline & $10-21-81$ & Xylene & 230 \\
\hline & $10-21-81$ & Ethyl benzene & 52 \\
\hline & $10-21-81$ & 1,2,4-Trime thyl benzene & 45 \\
\hline
\end{tabular}

* New York State Department of Health guideline for benzene is $5 \mathrm{\mu g} / \mathrm{L}$. Guideline for all other volatile organic chemicals listed is $50 \mathrm{\mu g} / \mathrm{L}$.

Data from Suffolk County Department of Health Services. 


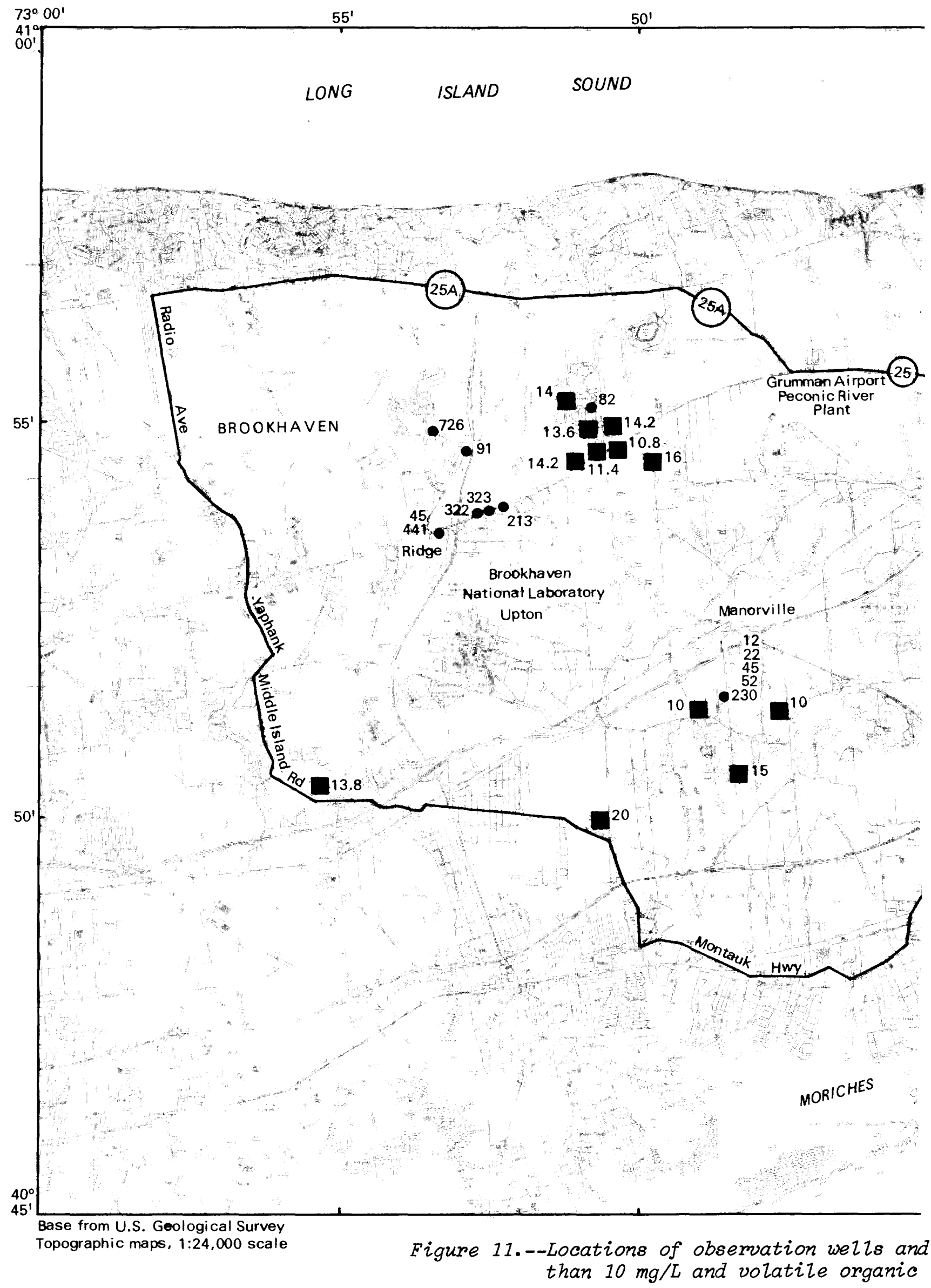




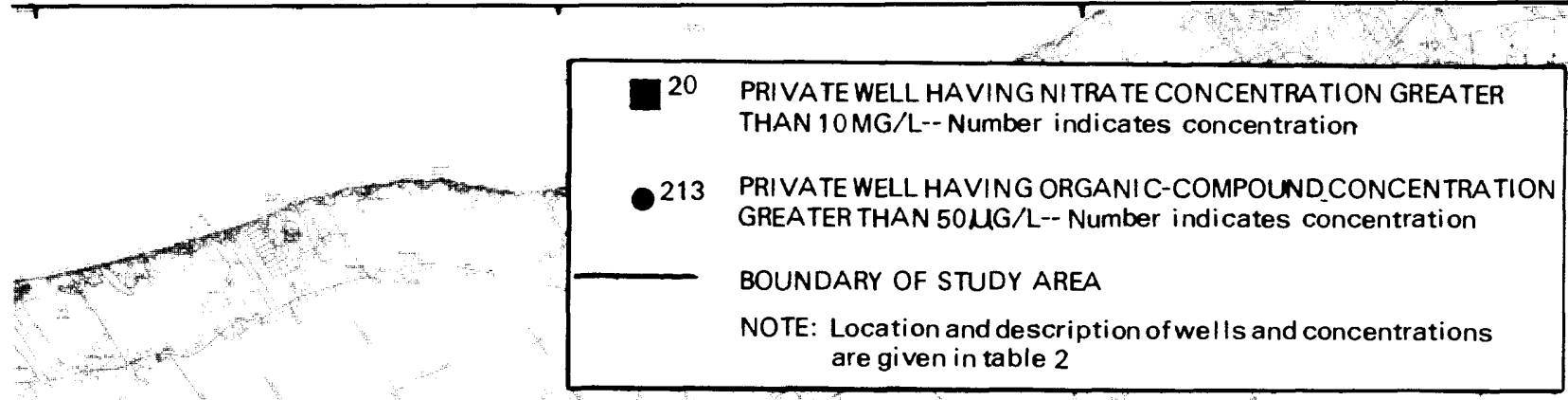
are given in table 2

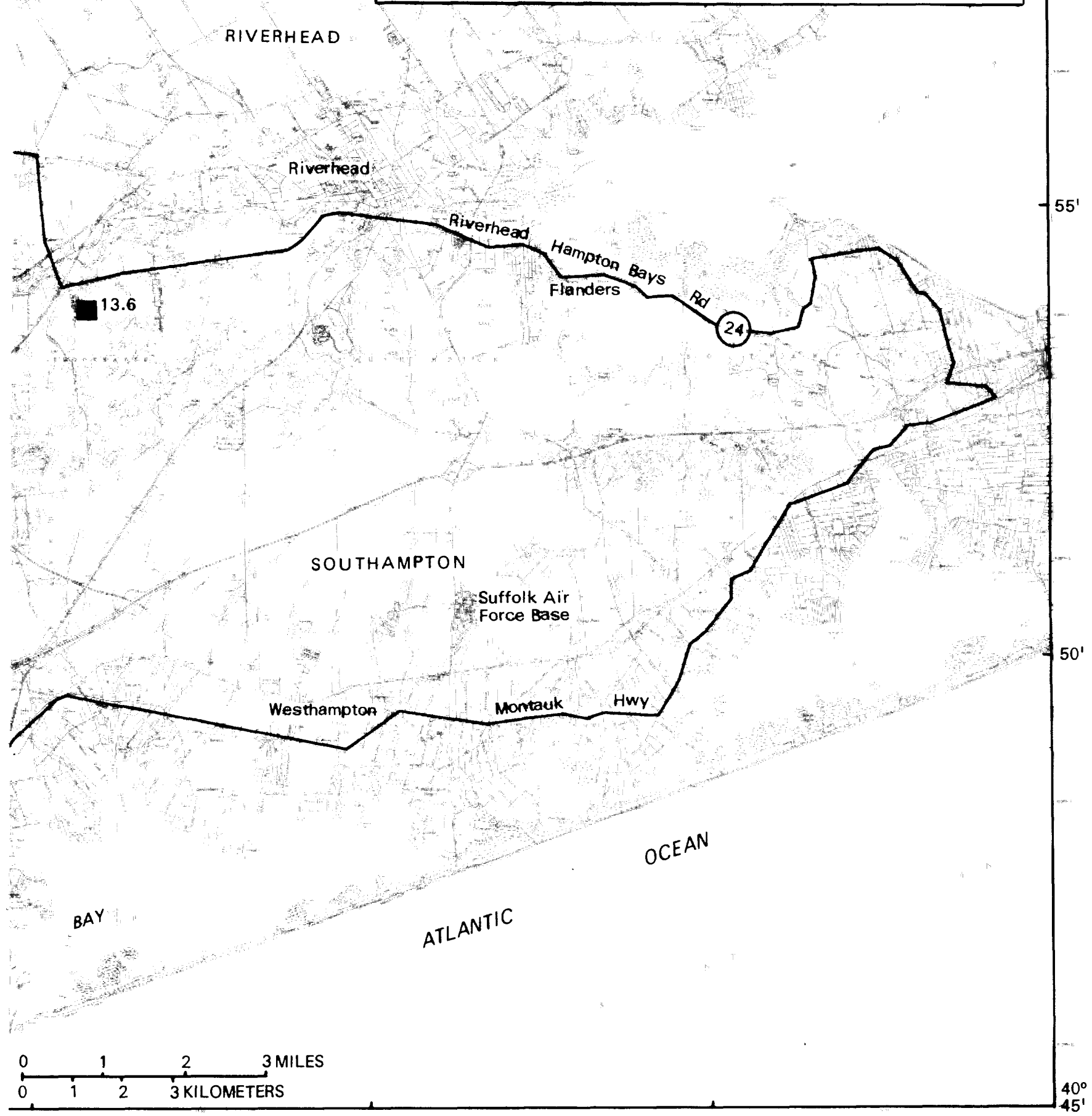

private wells having nitrate concentrations greater chemical concentrations greater than $50 \mu \mathrm{g} / L$. 
The residential area adjacent to Lake Panamoka in northern Ridge (fig. 11) is the only location within the Pine Barrens that shows localized nitrate-nitrogen contamination. Four wells in this area had a sample in excess of $10 \mathrm{mg} / \mathrm{L} \mathrm{NO}_{3}{ }^{-}$. The area surrounding Lake Panamoka is extensively developed, with housing on small lots and with septic tanks close to shallow private drinking-water wells. A private we11 on Panamoka Trail also had a sample containing $82 \mathrm{\mu g} / \mathrm{L}$ of $1,1,1-t r i c h l o r o e t h a n e$, and two other private wells nearby had $1,1,1$-trichloroethane concentrations of $27 \mu \mathrm{g} / \mathrm{L}$ and $10 \mu \mathrm{g} / \mathrm{L}$. These incidents of contamination have been attributed to chemical additives applied to a nearby cesspool that was failing.

The detection of $0-x y l e n e(45 \mu \mathrm{g} / \mathrm{L})$ and benzene $(441 \mu \mathrm{g} / \mathrm{L})$ in the we11 on Ruth Lane in Ridge (table 2) was attributed to a gasoline leak from a gas station on Route 25 north of this location. Further ground-water testing would be advisable because the Suffolk County Water Authority plans to develop a well field at Sally Lane, east of the contaminated private well (fig. 2 ).

Three agricultural areas within the Pine Barrens are currently being monitored for aldicarb and carbofuran contamination in private we1ls. The first is the Mount Sinai area, at the northwest corner of the study area; the second is at Calverton, near the Grumman Airport facility, and the third is in the south-central part of the area bordered by South Road, Wading River Road, Sunrise Highway, and Weeks Avenue (fig. 2).

\section{Surface Water}

Synthetic detergents (commonly referred to as methylene blue active substance or MBAS) in the streams and ground water have caused considerable concern in parts of Long Island (Perlmutter and others, 1964, p. 171) because their presence indicates contamination by septic-tank effluent or other wastewater. The U.S. Public Health Service has recommended that concentrations of synthetic detergents in water not exceed $0.5 \mathrm{mg} / \mathrm{L}$. Samples have been taken at 13 streams in the area on a semiannual basis since about 1960; results of the last three samplings are given in table 3. None of the analyses show excessive amounts of synthetic detergents, and none of the streams contained concentrations higher than $0.24 \mathrm{mg} / \mathrm{L}$.

\section{Sewage-Treatment Plants}

The Pine Barrens area contains 14 sewage-treatment plants; locations are shown in figure 12. Table 11 (at end of report) lists these plants and indicates the type of treatment, the design and average flow, the type of treatment process, the type of recharge and sludge facility, sludge-disposal quantity, and site locations. Six of these facilities provide denitrification, six provide secondary treatment, and two provide only primary treatment. Two of the plants have measured average flows between 1 and $1.5 \mathrm{Mgal} / \mathrm{d}$; the rest are well below $1 \mathrm{Mgal} / \mathrm{d}$. Twelve plants discharge their treated effluent to the ground through leaching pools or recharge beds, and two discharge it into the Peconic River. 
Table 3.-Concentrations of detergents (MBAS) in selected streams in the Pine Barrens, 1982-83. 1

[All values are in $\mathrm{mg} / \mathrm{L}$; locations are shown in $\mathrm{fig} .2$ ]

\begin{tabular}{|c|c|c|c|c|}
\hline \multirow[b]{2}{*}{ Stream station } & \multirow[b]{2}{*}{ Location } & \multicolumn{3}{|c|}{ MBAS concentration } \\
\hline & & $4-14-82$ & $10-13-82$ & $7-5-83$ \\
\hline Carmans River & $\begin{array}{l}\text { Bartlett Road, } \\
\text { Yaphank }\end{array}$ & $<0.02$ & $<0.02$ & 0.04 \\
\hline Carmans River & Gage site, Yaphank & $<.02$ & $<.02$ & .15 \\
\hline $\begin{array}{l}\text { West Branch } \\
\text { Forge River }\end{array}$ & $\begin{array}{l}\text { Montauk Highway, } \\
\text { Moriches }\end{array}$ & $<.02$ & $<.02$ & .06 \\
\hline $\begin{array}{l}\text { East Branch } \\
\text { Forge River }\end{array}$ & $\begin{array}{l}\text { Montauk Highway, } \\
\text { Moriches }\end{array}$ & $<.02$ & $<.02$ & $<.02$ \\
\hline Terrell River & $\begin{array}{l}\text { Montauk Highway, } \\
\text { Moriches }\end{array}$ & $<.02$ & $<.02$ & $<.02$ \\
\hline Peconic River & $\begin{array}{l}\text { Schultz Road, } \\
\text { Manorville }\end{array}$ & $<.02$ & $<.02$ & .07 \\
\hline Peconic River & $\begin{array}{l}\text { Gage site, } \\
\text { Rive rhead }\end{array}$ & $<.02$ & $<.02$ & .07 \\
\hline $\begin{array}{l}\text { Little Seatuck } \\
\text { Creek }\end{array}$ & $\begin{array}{l}\text { Montauk Highway, } \\
\text { Eastport }\end{array}$ & $<.02$ & .24 & $<.02$ \\
\hline Seatuck Creek & $\begin{array}{l}\text { Montauk Highway, } \\
\text { Eastport }\end{array}$ & $<.02$ & $<.02$ & $<.02$ \\
\hline East River & $\begin{array}{l}\text { Montauk Highway, } \\
\text { Eastport }\end{array}$ & $<.02$ & $<.02$ & $<.02$ \\
\hline Beaverdam Creek & $\begin{array}{l}\text { Montauk Highway, } \\
\text { Westhampton }\end{array}$ & $<.02$ & $<.02$ & $<.02$ \\
\hline Aspatuck Creek & $\begin{array}{l}\text { Brook Road, } \\
\text { Westhampton }\end{array}$ & $<.02$ & $<.02$ & .13 \\
\hline Quantuck Creek & $\begin{array}{l}\text { Meetinghouse Road, } \\
\text { Quogue }\end{array}$ & $<.02$ & .18 & $<.02$ \\
\hline
\end{tabular}

1 Analyses by Suffolk County Water Authority.

The collection systems for all facilities consist of separate sanitary sewers; two are municipal facilities, and the remaining 12 treatment plants are owned and operated privately (table 11). The County is making an effort to acquire facilities 111 and 115 (table 11) but does not plan to acquire any other private facilities in the area. However, sewer-agency contracts for owners of facilities serving condominiums and subdivisions (in this case treatment plants $35,70,76$, and 98 ) contain provisions to request County takeover if both the owner and County so desire.

State Pollutant Discharge Elimination System (SPDES) requirements for effluent have been revised; two major modifications are as follows:

1. Fecal coliform and chlorine limits will be eliminated for facilities that discharge effluent into subsurface leaching pools.

2. After August 31,1982 , al1 plants that discharge to ground water without denitrification must be upgraded to meet a total nitrogen limit of $10 \mathrm{mg} / \mathrm{L}$. 


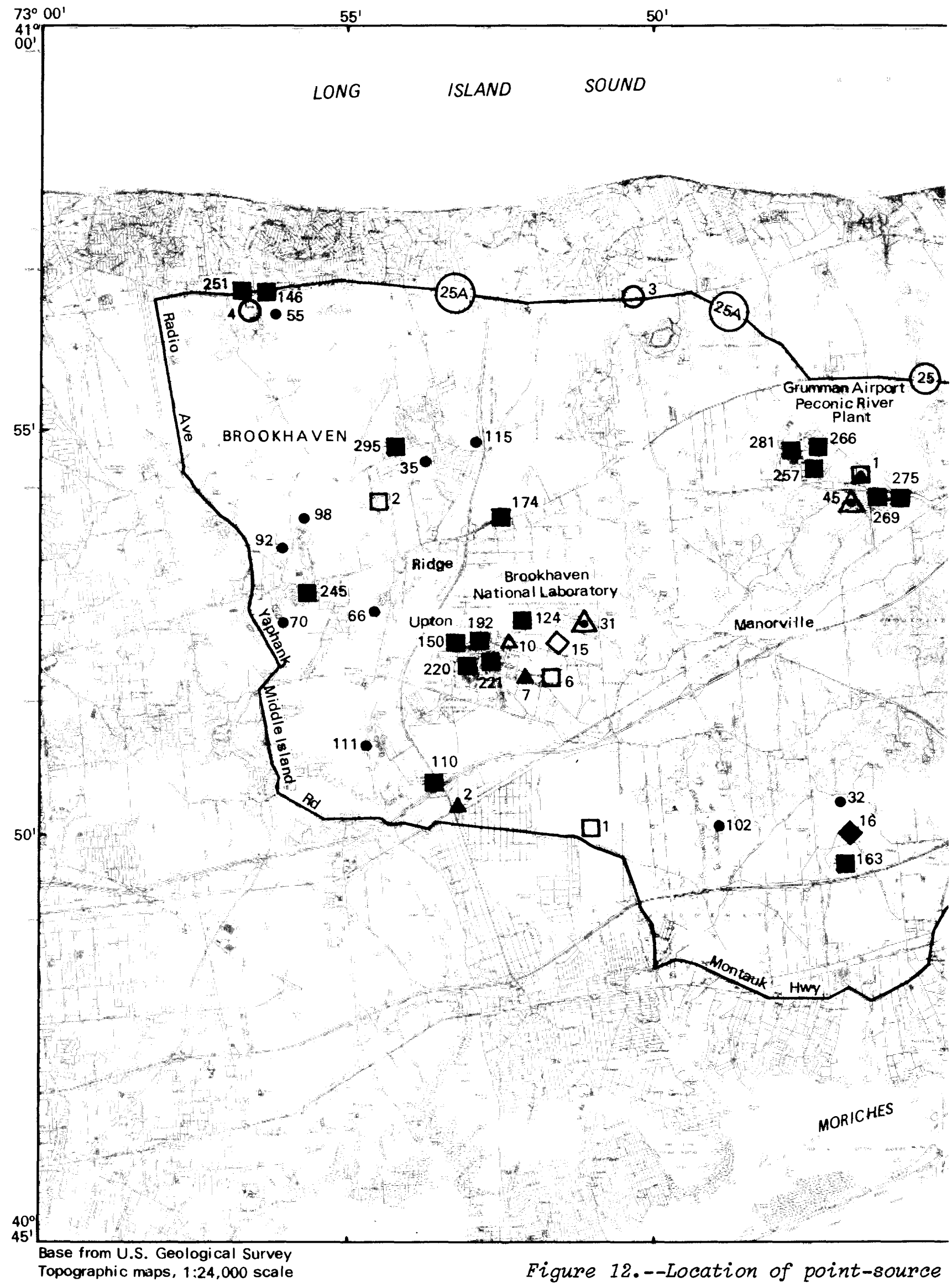




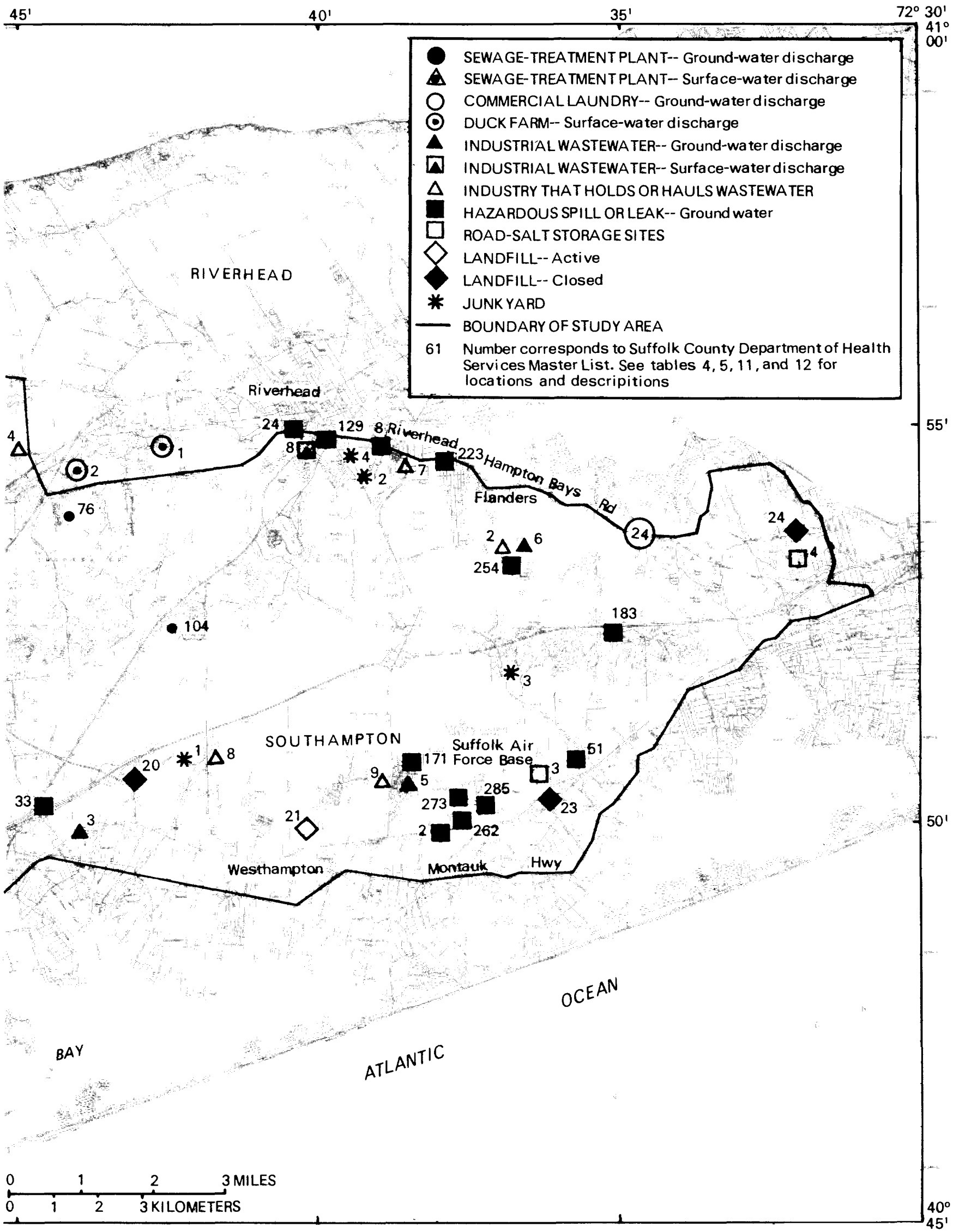

contamination in Pine Barrens. 
Surveillance reports indicate that 10 of the 14 facilities are attaining their effluent requirements for a permit. An assessment survey by the Suffolk County Department of Health Services in 1980 found that, in general, the major causes of the failures to meet effluent limits were inadequate operation and maintenance procedures rather than improper design or construction. As a result of these findings, owners have been advised of the necessary corrective actions and been given a compliance schedule.

Several of the facilities have had long-term operating problems and(or) require upgrading to meet the revised nitrogen standard. Malfunction of process equipment and failing ponding facilities are the two most common serious difficulties.

Samples from 10 of the 14 treatment plants in the area were within the limits of $30 \mathrm{mg} / \mathrm{L}$ (daily average) for suspended solids and $10 \mathrm{\mu g} / \mathrm{L}$ for total nitrogen. Samples from the remaining four plants exceeded the limits as a result of mechanical difficulties. The results are based on four samples taken by the Suffolk County Department of Health Services.

\section{Areas of Point-Source Contamination}

The Suffolk County Department of Health Services has reported groundwater contamination from point sources in some areas. Locations, chemical type, and approximate volume are given in table 12 (at end of report). Plans for remedial action have not yet been disclosed.

Several other commercial and industrial sources may also contribute chemical pollutants to the area; locations of industrial discharges, commercial laundries, junkyards, road-salt storage sites, duck farms, landfills, and industries that haul or hold wastewater are shown in figure 12 with the locations of documented point sources in the Pine Barrens. Data on the industrial sources and discharges are given in tables 4 and 5.

Table 4.--Industries that hold or haul wastewater in the Pine Barrens.

[Locations are shown in fig. 12]

\begin{tabular}{rcl}
\hline No. & SPDES No. 1 & \multicolumn{1}{c}{ Type } \\
\hline 2 & NY-0136824 & Photographic and printing \\
3 & None & Waste oils \\
4 & None & Waste oil and fluid \\
7 & None & Photographic \\
8 & None & Copper chromate and arsenate used \\
9 & None & Pesticide storage \\
10 & None & 1) Sulfuric acid \\
& 2) Dry radioactive waste \\
& 3) Solvents stored and used \\
& 4) Waste oils \\
\hline
\end{tabular}

1 State Pollutant Discharge Elimination System Permit number. No wastewater discharges allowed. 
Table 5.--Industrial wastewater discharges in the Pine Barrens.

[NR, not reported; GW, ground water. Locations are shown in fig. 12; data from Suffolk County Department of Health Services]

\begin{tabular}{|c|c|c|c|c|c|}
\hline No. & SPDES No. 1 & Type of industry & $\begin{array}{l}\text { Process } \\
\text { water flow } \\
(\mathrm{gal} / \mathrm{d})\end{array}$ & $\begin{array}{l}\text { Days of } \\
\text { discharge } \\
\text { per week }\end{array}$ & $\begin{array}{c}\text { Discharged } \\
\text { to: }\end{array}$ \\
\hline 1 & $\mathrm{NY}-0025453$ & $\begin{array}{l}\text { Aircraft assembly, } \\
\text { metal finishing }\end{array}$ & 1,500 & 5 & $\begin{array}{c}\text { Surface water } \\
\text { via sewage- } \\
\text { treatment } \\
\text { plant }\end{array}$ \\
\hline 2 & In Process & Pharmaceuticals & 1,500 & 5 & GW \\
\hline 3 & $N Y-0098779$ & Duck vaccines & $<100$ & 5 & GW \\
\hline 5 & None & Pipe manufacturing & NR & 5 & GW \\
\hline 6 & None & Metal etching & $<100$ & 5 & GW \\
\hline \multirow[t]{7}{*}{7} & None & $\begin{array}{l}\text { PC board etch and } \\
\text { degreasing, acid } \\
\text { rain manufacturing }\end{array}$ & NR & NR & GW \\
\hline & & Paint and thinners & NR & NR & GW \\
\hline & & $\begin{array}{l}\text { Metal etching and } \\
\text { silk screening }\end{array}$ & NR & NR & GW \\
\hline & & $\begin{array}{l}\text { Acid waste and } \\
\text { solvents }\end{array}$ & NR & NR & GW \\
\hline & & $\begin{array}{l}\text { Liquid hydrogen, } \\
\text { liguid deuterium, } \\
\text { wash water }\end{array}$ & NR & NR & GW \\
\hline & & $\begin{array}{l}\text { Steam cleaning and } \\
\text { quench water }\end{array}$ & NR & NR & GW \\
\hline & & $\begin{array}{l}\text { Backwash water } \\
\text { (high iron) }\end{array}$ & NR & NR & GW \\
\hline 8 & $N Y-0101567$ & $\begin{array}{l}\text { Photographic rinse } \\
\text { water }\end{array}$ & Unknown & 5 & $\begin{array}{c}\text { Surface water } \\
\text { via sewage- } \\
\text { treatment } \\
\text { plant }\end{array}$ \\
\hline
\end{tabular}

1 State Pollutant Discharge Elimination System Permit number. 


\section{WATER USE AND PUMPAGE}

Ground water is the only source of water supply for Nassau and Suffolk Counties. A majority of the water in the Pine Barrens is obtained from the upper glacial (water-table) aquifer; the rest is obtained from the Magothy and Lloyd (deep) aquifers. At present, Suffolk County Water Authority supplies the majority of the water in the area; the rest is supplied by several smaller companies.

Total public water-supply withdrawal in the area in 1982 is estimated to have been $9.09 \mathrm{Mgal} / \mathrm{d}$. In $1982,7.88 \mathrm{Mgal} / \mathrm{d}$ was withdrawn from the upper glacial aquifer; $1.02 \mathrm{Mga} / \mathrm{d}$ was withdrawn from the Magothy aquifer, and 0.19 Mgal/d from the Lloyd aquifer.

Ground water is also used for irrigation. Pumpage for farm and golf course irrigation is unknown but is estimated to be less than $0.5 \mathrm{Mgal} / \mathrm{d}$, solely from the upper glacial aquifer.

The upper glacial and Magothy aquifers are capable of producing considerably more water than is currently being withdrawn; use of the Lloyd aquifer is legally restricted. The upper glacial aquifer is the most readily available source, but if it should prove inadequate for a particular need, wells could be drilled to the underlying Magothy in the central part of the Pine Barrens. Withdrawal from the Lloyd aquifer is restricted by New York State legislation to the south-shore barrier islands and to other areas with specific supply problems. Brookhaven National Laboratories is one agency that has permission to pump from the Lloyd aquifer.

\section{Public Water Supply}

The Pine Barrens area contains 31 public-supply wells. The Suffolk County Water Authority, which is the major public water supplier within the area, operates 15 wells in six well fields within the Pine Barrens. Well-field locations and pumpage data are given in table 6 .

In addition to these sites, the Suffolk County Water Authority plans to develop well fields at four new sites, three of which are Longwood Road, Sally Lane, and Railroad Avenue ( $f i g .2$ ); the fourth is at Evergreen Avenue within the Westhampton Beach District service area.

Shorewood Water Company, which extends into the study area, operates two wells from its well field at Bridgewater Drive. Calverton Hills Association in Calverton and Ridge Rest Home on Whiskey Road in Ridge both operate their own we1ls.

Eastern Suffolk Water Corporation services residents along the western border of the study area, but its well field is west of the study-area boundary (fig. 2). Riverside Water District, which is south of Riverhead Town, also has its service area within the Pine Barrens study area but purchases its water supply from the Riverhead Water District, which is outside the study area boundary. 
Table 6.--Estimated public-supply withdrawals by Suffolk County water Authority and private well companies in the Pine Barrens, 1982.

[Locations are shown in fig. 2; data from Suffolk County water Authority and New York State Department of Environmental Conservation; dashes indicate data unavailable]

\begin{tabular}{|c|c|c|c|c|c|c|}
\hline \multirow[b]{2}{*}{ Location } & \multirow{2}{*}{$\begin{array}{c}\text { We11 } \\
\text { number } \\
\text { and } \\
\text { aquifer } 1 \\
\end{array}$} & \multirow[b]{2}{*}{$\begin{array}{l}\text { Depth } \\
(\mathrm{ft})\end{array}$} & \multirow[b]{2}{*}{$\begin{array}{l}\text { Design } \\
\text { capacity } \\
\text { (gal/min) }\end{array}$} & \multicolumn{3}{|c|}{$\begin{array}{c}\text { Total pumpage, by we11 } \\
\text { field, in Mgal } \\
\end{array}$} \\
\hline & & & & Annual & $\begin{array}{c}\text { Average } \\
\text { daily }\end{array}$ & $\begin{array}{l}\text { Peak } \\
\text { daily }\end{array}$ \\
\hline Bailey Road & $\begin{array}{l}36711(G) \\
40161(G) \\
49606(M)\end{array}$ & $\begin{array}{l}137 \\
143 \\
389\end{array}$ & $\begin{array}{l}1,700 \\
1,700 \\
1,200\end{array}$ & 153 & 0.42 & 1.08 \\
\hline $\begin{array}{l}\text { William Floyd } \\
\text { Parkway }\end{array}$ & $\begin{array}{l}47436(G) \\
47437(G) \\
47438(M)\end{array}$ & $\begin{array}{l}167 \\
179 \\
269\end{array}$ & $\begin{array}{l}1,700 \\
1,700 \\
1,400\end{array}$ & 19.7 & .05 & .09 \\
\hline $\begin{array}{l}\text { Country Club } \\
\text { Drive }\end{array}$ & $\begin{array}{l}56038(G) \\
56039(G)\end{array}$ & $\begin{array}{l}158 \\
163\end{array}$ & $\begin{array}{l}1,900 \\
1,900\end{array}$ & 64.8 & .18 & .30 \\
\hline $\begin{array}{l}\text { Moriches-River- } \\
\text { head Road }\end{array}$ & $\begin{array}{l}53522(\mathrm{G}) \\
53851(\mathrm{M})\end{array}$ & $\begin{array}{l}242 \\
297\end{array}$ & $\begin{array}{r}300 \\
1,400\end{array}$ & 7.2 & .02 & .05 \\
\hline Spinny Road & $\begin{array}{l}23184(G) \\
53593(G)\end{array}$ & $\begin{array}{l}118 \\
162\end{array}$ & $\begin{array}{l}2,000 \\
2,000\end{array}$ & 179.3 & .49 & .93 \\
\hline $\begin{array}{l}\text { Bridgewater } \\
\text { Drive }^{2}\end{array}$ & $\begin{array}{l}37991(G) \\
65341(G)\end{array}$ & $\begin{array}{l}146 \\
146\end{array}$ & $\begin{array}{l}2,100 \\
2,100\end{array}$ & 228.3 & .63 & -- \\
\hline $\begin{array}{l}\text { Calverton } \\
\text { Hills }{ }^{2}\end{array}$ & $\begin{array}{l}47281(G) \\
47282(G)\end{array}$ & $\begin{array}{l}275 \\
283\end{array}$ & $\begin{array}{l}1,080 \\
1,080\end{array}$ & 19.3 & .05 & - \\
\hline $\begin{array}{l}\text { Ridge Rest } \\
\text { Home }\end{array}$ & $--\quad(G)$ & 230 & 20 & 2.5 & .007 & -- \\
\hline $\begin{array}{l}\text { 01d Country } \\
\text { Road }\end{array}$ & $\begin{array}{l}16892(G) \\
16893(G) \\
65905(G) \\
\end{array}$ & $\begin{array}{r}70 \\
76 \\
161 \\
\end{array}$ & $\begin{array}{l}1,700 \\
1,700 \\
1,700 \\
\end{array}$ & 144.5 & .40 & 1.11 \\
\hline
\end{tabular}

$1 G$, upper glacial aquifer; $M$, Magothy aquifer.

2 Private well companies that supply water.

\section{Brookhaven Nationai Laboratory Water Supply}

The major user of water in the Pine Barrens is Brookhaven National Laboratory, with an average annual pumpage of 2.4 billion gallons. The 14 we11s on the property of Brookhaven National Laboratory are used for a variety of purposes ranging from cooling, which is the major use, to drinking water. Pumpage and other data on these wells are given in table 7 . 
Table 7.--Estimated public-supply withdrawals by Brookhaven
National Laboratory, 1982.

[Locations are shown in fig. 2; data from New York State Department of Envi ronmental Conservation]

\begin{tabular}{lcccc}
\hline $\begin{array}{l}\text { We11 } \\
\text { number }\end{array}$ & $\begin{array}{c}\text { Depth } \\
\text { (ft) }\end{array}$ & Aquifer & $\begin{array}{c}\text { Design } \\
\text { capacity } \\
\text { (gal/min) }\end{array}$ & $\begin{array}{c}\text { Yearly total } \\
\text { (Mgal) }\end{array}$ \\
\hline S 2476 & 101 & Upper Glacial & 500 & 63.1 \\
S 3197 & 135 & Upper Glacial & 500 & 40.1 \\
S 17836 & 147 & Upper Glacial & 1,200 & 66.1 \\
S 22151 & 151 & Upper Glacial & 1,200 & 223.6 \\
S 22150 & 150 & Upper Glacial & 1,200 & 618.9 \\
S 15949 & 119 & Upper Glacial & 825 & not in service \\
S 15950 & 110 & Upper Glacial & 950 & 298.5 \\
S 15951 & 102 & Upper Glacial & 1,000 & 232.0 \\
S 14977 & 298 & Magothy & 1,200 & 172.4 \\
S 18703 & 145 & Upper Glacial & 1,300 & 210.8 \\
& & & & not in service \\
S 6434 & 1,392 & Lloyd & 450 & 74.8 \\
S 66944 & 140 & Upper Glacial & 1,200 & 214.5 \\
S 6697 & 102 & Upper Glacial & 700 & 161.9 \\
S 72038 & -- & -- & 1,200 & \\
\hline
\end{tabular}

Total yearly pumpage $= \pm 2.4$ billion gallons.

\section{SUMMARY AND CONCLUSIONS}

Ground water is the sole source of water supply for central and eastern Long Island. Increasing urbanization and industrialization have altered the quality of water in parts of the aquifers to the extent that some of the water has become impotable. One area of Long Island that has been proposed as a source of high-quality ground water is a part of Long Island's Pine Barrens in southeastern Suffolk County. The usefulness of this water source depends upon the amount of precipitation, the rate of recharge, and the chemical quality of the ground water.

The basement of the Pine Barrens area is Precambrian bedrock overlain by Cretaceous, Pleistocene, and Holocene deposits that contain three distinguishable aquifers. The surficial material consists of morainal and outwash deposits overlain by recent beach and marsh deposits.

Precipitation is the only source of recharge to the island's ground-water system. Of the average annual precipitation of 46.3 inches, about $22.6 \mathrm{in} / \mathrm{yr}$ reaches the ground-water reservoir. Overland runoff is estimated to be about $0.5 \mathrm{in} / \mathrm{yr}$, and average annual evapotranspiration is estimated to be 23.2 in/yr. 
The three aquifers that underlie the Pine Barrens in Suffolk County are capable of producing more than the current $9.09 \mathrm{Mgal} / \mathrm{d}$ withdrawal. Both the upper glacial and Magothy aquifers are readily available sources for supplying additional needs. At present, it is unlikely that the Lloyd aquifer would be needed as a source of ground water except in special cases.

Ground water in the Pine Barrens is generally of a quality suitable for drinking and most other uses, except locally where point-source contamination has occurred.

\section{REFERENCES CITED}

Bart, Jeffrey, and others, 1976, Preliminary hydrologic investigations of the south fork of Long Island: Princeton, N.J., Princeton University Water Resources Program WRP-76-1, P. A1-G36.

Cohen, Philip, Franke, 0. L., and Foxworthy, B. L., 1968, An atlas of Long Island's water resources: New York State Water Resources Commission Bulletin 62, 117 p.

Cohen, Philip, Franke, O. L., and McClymonds, N. E., 1969, Hydrologic effects of the 1962-66 drought on Long Island, New York: U.S. Geological Survey Water-Supply Paper 1879-F, p. F1-F18.

Fuller, M. L., 1914, The geology of Long Island, New York: U.S. Geological Survey Professional Paper 82, $231 \mathrm{p}$.

Donaldson, C. D., and Koszalka, E. J., 1982a, Potentiometric surface of the Magothy aquifer, Long Island, New York, in March 1979: U.S. Geological Survey Open-File Report 82-160, 2 sheets.

1982b, Potentiometric surface of the Lloyd aquifer, Long Island, New York, in January 1979: U.S. Geological Survey Open-File Report $82-162,2$ sheets.

1982c, Water table on Long Island, New York, March 1979: U.S. Geological Survey Open-File Report 82-163, 2 sheets.

Holzmacher, McLendon, and Murre11, 1968, Comprehensive public water supply study, Suffolk County, New York: Melville, N.Y., Holzmacher, McLendon, and Murre11, CPWS-24, $3 \mathrm{v}$.

Jensen, H. M., and Soren, Julian, 1974, Hydrogeology of Suffolk County, Long Island, New York: U.S. Geological Survey Hydrologic Investigation Atlas HA-501, 2 sheets.

Long Island Lighting Company: Population Survey 1981, Current population estimates for Nassau and Suffolk Counties, New York, 46 p. 


\section{REFERENCES CITED (continued)}

Miller, J. F., and Frederick, R. H., 1969, The precipitation regime of Long Island, New York: U.S. Geological Survey Professional Paper 627-A, 21 p.

Nakao, J. H., and Erlichman, F. R., 1978, The water table on Long Island, New York, in March 1975: U.S. Geological Survey Open-File Report 78-569, $10 \mathrm{p}$.

Perlmutter, N. M., Lieber, Maxim, and Frauentha1, H. L., 1964, Contamination of ground water by detergents in a suburban envi ronment - South Farmingdale area, Long Island, New York: U.S. Geological Survey Professional Paper 501-C, p. 170-175.

Prince, K. R., 1976, The potentiometric surface of the Magothy aquifer on Long Island, New York, in March 1975: U.S. Geological Survey Open-File Report $76-536,12 \mathrm{p}$.

Suter, Russe11, delaguna, Wallace, and Perlmutter, N. M., 1949, Mapping of geologic formations and aquifers of Long Island, New York: New York State Water Power and Control Commission Bulletin GW-18, 212 p.

U.S. Geological Survey, Water resources data for New York, Volume 2--Long Island: U.S. Geological Survey water-data report (issued annually).

U.S. Public Health Service, 1962, Drinking water standards: U.S. Public Health Service Publication 956, 61 p.

Warren, M. A., delaguna, Wallace, and Lusczynski, N. J., 1968, Hydrology of Brookhaven National Laboratory and vicinity, Suffolk County, New York: U.S. Geological Survey Bulletin 1156-C, 127 p., 10 pl. 
Tables 8 through 12

Page

Table 8.--Hater levels in wells in the Pine Barrens, September 1983. . 40

9.--Discharge of selected streams in the Pine Barrens,

1982-83. . . . . . . . . . . . . . 4 42

10.--Concentrations of nitrate-nitrogen in water from selected

Suffolk County Department of Health Services observation

wells in the Pine Barrens, 1972-83 . . . . . . . . . 44

11.--Sewage-treatment plants in the Pine Barrens. . . . . . . 50

12.--Documented point sources of ground-water contaminants in

the Pine Barrens .. . . . . . . . . . 52 
Table 8.-Water levels in wells in the Pine Barrens, September 1983.

[All water levels are in feet above sea level]

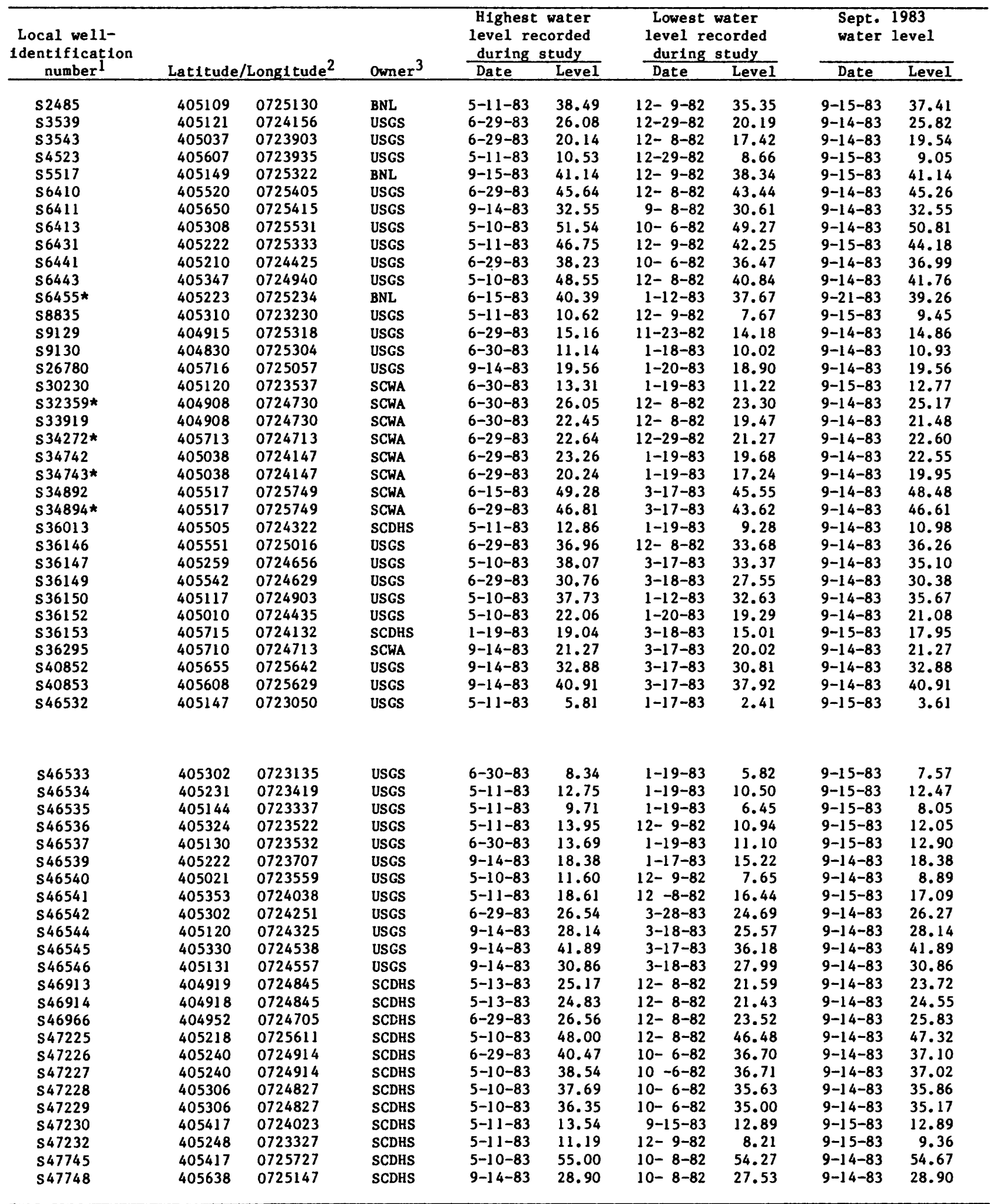

T, Suffolk County

2 Should be read $40^{\circ} 51^{\prime} 09^{\prime} 072^{\circ} 51^{\prime} 30^{\prime \prime}$

3 BNL, Brookhaven National Laboratory; USGS, U.S. Geological Survey; SCWA, Suffolk County Water Authority; SCDHS, Suffolk County Department of Health Services.

* Magothy wells. 
Table 8.-Water levels in wells in the Pine Barrens, September 1983 (continued)

[A11 water levels are in feet above sea level]

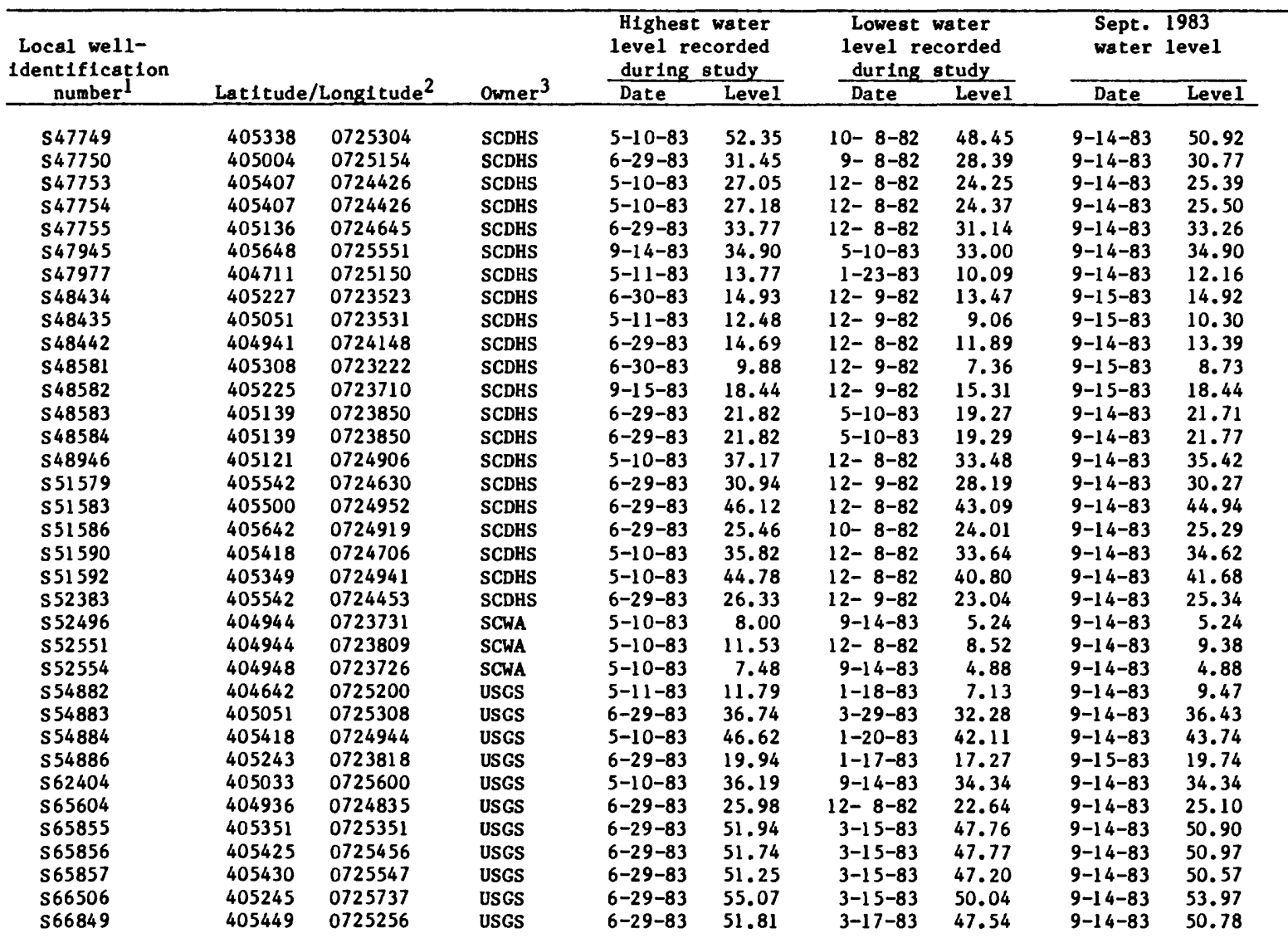

\begin{tabular}{|c|c|c|c|c|c|c|c|c|c|}
\hline 572176 & 404955 & 0725406 & USGS & $6-29-83$ & 22.26 & $11-23-82$ & 21.47 & $9-14-83$ & 21.83 \\
\hline s72177 & 405023 & 0725548 & USGS & $5-10-83$ & 33.60 & $11-22-82$ & 32.54 & $9-14-83$ & 32.81 \\
\hline S73950 & 404802 & 0725213 & USGS & $6-29-83$ & 15.85 & $11-22-82$ & 13.42 & $9-14-83$ & 14.49 \\
\hline S 74287 & 405201 & 0725443 & USGS & $6-29-83$ & 47.24 & $9-15-83$ & 46.34 & $9-15-83$ & 46.34 \\
\hline s74289 & 405418 & 0725112 & USGS & $5-10-83$ & 48.63 & $9-14-83$ & 46.53 & $9-14-83$ & 46.53 \\
\hline S74290 & 405530 & 0724832 & USGS & $6-29-83$ & 40.92 & $9-14-83$ & 40.10 & $9-14-83$ & 40.10 \\
\hline s74291 & 405421 & 0724745 & USGS & $6-29-83$ & 39.61 & $9-14-83$ & 39.28 & $9-14-83$ & 39.28 \\
\hline S74292 & 405322 & 0724541 & USGS & $6-29-83$ & 39.70 & $5-10-83$ & 38.76 & $9-14-83$ & 38.88 \\
\hline S74293 & 405017 & 0724950 & USGS & $6-29-83$ & 32.45 & $5-10-83$ & 31.04 & $9-14-83$ & 31.43 \\
\hline S74294 & 405213 & 0724811 & USGS & $5-11-83$ & 39.30 & $9-15-83$ & 36.28 & $9-15-83$ & 36.28 \\
\hline S74295 & 405045 & 0724726 & USGS & $6-29-83$ & 31.50 & $5-10-83$ & 29.75 & $9-14-83$ & 31.00 \\
\hline s74296 & 405347 & 0723855 & USGS & $5-11-83$ & 16.94 & $9-15-83$ & 14.35 & $9-15-83$ & 14.35 \\
\hline s74297 & 405338 & 0724305 & USGS & $6-30-83$ & 37.32 & $5-11-83$ & 35.79 & $9-15-83$ & 36.80 \\
\hline S74298 & 405348 & 0723705 & USGS & $6-30-83$ & 16.66 & $9-15-83$ & 15.64 & $9-15-83$ & 15.64 \\
\hline S74299 & 405340 & 0723406 & USGS & $5-11-83$ & 12.59 & $9-15-83$ & 8.65 & $9-15-83$ & 8.65 \\
\hline s74300 & 405115 & 0723705 & USGS & $6-29-83$ & 17.49 & $5-10-83$ & 16.08 & $9-14-83$ & 17.02 \\
\hline s74301 & 405330 & 0724539 & USGS & $9-14-83$ & 41.02 & $5-10-83$ & 38.92 & $9-14-83$ & 41.02 \\
\hline s74302 & 405434 & 0724214 & USGS & $5-11-83$ & 21.41 & $9-15-83$ & 20.05 & $9-15-83$ & 20.05 \\
\hline S74303 & 405435 & 0724214 & USGS & $5-11-83$ & 16.85 & $9-15-83$ & 14.61 & $9-15-83$ & 14.61 \\
\hline S74304 & 405419 & 0723812 & USGS & $5-11-83$ & 10.47 & $9-15-83$ & 8.44 & $9-15-83$ & 8.44 \\
\hline s74305 & 405404 & 0723202 & USGS & $6-30-83$ & 15.24 & $9-15-83$ & 14.62 & $9-15-83$ & 14.62 \\
\hline s74306 & 405033 & 0724025 & USGS & $6-30-83$ & 20.03 & $9-14-83$ & 19.25 & $9-14-83$ & 19.25 \\
\hline S74307 & 405206 & 0724033 & USGS & $6-30-83$ & 24.74 & $5-10-83$ & 21.19 & $9-15-83$ & 23.77 \\
\hline S74308 & 405256 & 0723923 & USGS & $6-30-83$ & 22.29 & $5-11-83$ & 21.69 & $9-15-83$ & 22.21 \\
\hline
\end{tabular}

$1 \mathrm{~s}$, Suffolk County

2 Should be read $40^{\circ} 51^{\prime} 09^{\prime \prime} 072^{\circ} 51^{\prime} 30^{\prime \prime}$

3 BNL, Brookhaven National Laboratory; USGS, U.S. Geological Survey; SCWA, Suffolk County Water Authority; SCDHS, Suffolk County Department of Health Services.

* Magothy wells. 
Table 9.--Discharge of selected streams in the Pine Barrens, 1982-83.

[Locations are shown in fig. 2.]

\begin{tabular}{|c|c|c|c|c|}
\hline $\begin{array}{l}\text { Station } \\
\text { number }\end{array}$ & Station name & Location & Date & $\begin{array}{l}\text { Discharge } \\
\left(\mathrm{ft}^{3} / \mathrm{s}\right)\end{array}$ \\
\hline 01304400 & $\begin{array}{l}\text { Peconic River at } \\
\text { Manorville, N.Y. }\end{array}$ & $\begin{array}{l}\text { Lat } 40^{\circ} 52 \cdot 38 * \text {, long } 72^{\circ} 49 \cdot 42 * \text {, } \\
\text { Suf folk County at bridge on } \\
\text { Schultz Road, } 1 \mathrm{mi}(2 \mathrm{~km}) \\
\text { northwest of Manorville, and } \\
8.5 \mathrm{mi}(13.7 \mathrm{~km}) \text { upstream } \\
\text { from gaging station at } \\
\text { Riverhead. }\end{array}$ & $\begin{array}{r}7-20-82 \\
10-28-82 \\
9-1-83\end{array}$ & $\begin{array}{l}1.80 \\
2.90 \\
2.41\end{array}$ \\
\hline 01304510 & $\begin{array}{l}\text { Peconic River at } \\
\text { Nugent Drive, at } \\
\text { Riverhead, N.Y. }\end{array}$ & $\begin{array}{l}\text { Lat } 40^{\circ} 55^{\prime} 03^{\prime \prime}, \text { long } 72^{\circ} 40^{\prime} 11^{\prime \prime} \text {, } \\
\text { Suffolk County at bridge on } \\
\text { Nugent Drive at Riverhead, } \\
\text { and } 1.4 \mathrm{mi}(2.3 \mathrm{~km}) \text { down- } \\
\text { stream from gaging station } \\
\text { at Riverhead. }\end{array}$ & $\begin{array}{r}7-20-82 \\
10-28-82 \\
9-1-83\end{array}$ & $\begin{array}{l}26.00 \\
26.40 \\
41.20\end{array}$ \\
\hline 01304530 & $\begin{array}{l}\text { Little River near } \\
\text { Riverhead, N.Y. }\end{array}$ & $\begin{array}{l}\text { Lat } 40^{\circ} 53^{\prime} 52^{\prime \prime}, \text { long } 72^{\circ} 40^{\circ} 30^{\prime \prime} \text {, } \\
\text { Suf folk County, at Wildwood } \\
\text { Lake out let, } 500 \mathrm{ft}(152 \mathrm{~m}) \\
\text { east of Moriches-Riverhead } \\
\text { Road, } 1.5 \mathrm{mi}(2.4 \mathrm{~km}) \text { south- } \\
\text { west of Riverhead. }\end{array}$ & $\begin{array}{r}7-22-82 \\
9-8-82 \\
11-18-82 \\
4-7-83 \\
8-30-83\end{array}$ & $\begin{array}{l}4.10 \\
4.15 \\
6.48 \\
4.90 \\
2.97\end{array}$ \\
\hline 01304560 & $\begin{array}{l}\text { White Brook at } \\
\text { Riverhead, N.Y. }\end{array}$ & $\begin{array}{l}\text { Lat } 40^{\circ} 54^{\prime} 40^{\prime \prime} \text {, long } 72^{\circ} 38^{\prime} 37^{\prime \prime} \text {, } \\
\text { Suffolk County, at culvert } \\
\text { on State Highway } 24,1 \mathrm{mi} \\
(2 \mathrm{~km}) \text { southeast of River- } \\
\text { head. }\end{array}$ & $\begin{array}{r}7-22-82 \\
9-9-82 \\
11-18-82 \\
4-7-83 \\
9-1-83\end{array}$ & $\begin{array}{l}0.88 \\
0.89 \\
0.44 \\
3.76 \\
4.61\end{array}$ \\
\hline 01304745 & $\begin{array}{l}\text { Weesuck Creek at } \\
\text { East Quogue, N.Y. }\end{array}$ & $\begin{array}{l}\text { Lat } 40^{\circ} 50^{\prime} 52^{\prime \prime}, \text { long } 72^{\circ} 34^{\prime} 42^{\prime \prime} \text {, } \\
\text { Suf folk County, at culvert } \\
\text { on State Highway } 27 \mathrm{~A}, 0.5 \mathrm{mt} \\
(0.8 \mathrm{~km}) \text { northeast of East } \\
\text { Quogue. }\end{array}$ & $\begin{array}{r}7-26-82 \\
9-9-82 \\
12-27-82 \\
4-7-82 \\
9-1-83\end{array}$ & $\begin{array}{l}0.93 \\
0.88 \\
0.30 \\
1.49 \\
1.81\end{array}$ \\
\hline 01304760 & $\begin{array}{c}\text { Quantuck Creek at } \\
\text { Quogue, N.Y. }\end{array}$ & $\begin{array}{l}\text { Lat } 40^{\circ} 49^{\prime} 57^{\prime \prime} \text {, long } 72^{\circ} 37^{\prime} 06^{\prime \prime} \text {, } \\
\text { Suf folk County, at culvert } \\
\text { on 0ld Meeting House Road, } \\
1 \mathrm{mi}(2 \mathrm{~km}) \text { northwest of } \\
\text { Quogue. }\end{array}$ & $\begin{array}{r}7-26-82 \\
9-8-82 \\
12-27-82 \\
4-7-83 \\
8-30-83\end{array}$ & $\begin{array}{l}1.40 \\
1.12 \\
1.87 \\
2.21 \\
1.07\end{array}$ \\
\hline 01304780 & $\begin{array}{l}\text { Aspatuck Creek near } \\
\text { Westhampton Beach, } \\
\text { N.Y. }\end{array}$ & $\begin{array}{l}\text { Lat } 40^{\circ} 49^{\prime} 04 \text {, long } 72^{\circ} 38^{\prime} 13^{\prime \prime} \text {, } \\
\text { Suffolk County, at culvert } \\
\text { on Brook Road, at } \\
\text { Westhampton Beach. }\end{array}$ & $\begin{array}{r}7-26-82 \\
9-8-82 \\
12-27-82 \\
4-7-83 \\
8-30-83\end{array}$ & $\begin{array}{l}1.70 \\
1.24 \\
0.96 \\
3.11 \\
1.07\end{array}$ \\
\hline 01304800 & $\begin{array}{l}\text { Beaverdam Creek at } \\
\text { Westhampton Beach, } \\
\text { N.Y. }\end{array}$ & $\begin{array}{l}\text { Lat } 40^{\circ} 49^{\prime} 23^{\prime \prime}, \text { long } 72^{\circ} 39^{\prime} 42^{\prime \prime} \text {, } \\
\text { Suffolk County, at culvert } \\
\text { on 01d County Road, } 100 \mathrm{ft} \\
(30 \mathrm{~km}) \text { northwest of State } \\
\text { Highway } 27 \mathrm{~A} \text { and } 1 \mathrm{mi}(2 \mathrm{~km}) \\
\text { northwest of Westhampton. }\end{array}$ & $\begin{array}{r}7-22-82 \\
9-8-82 \\
12-27-82 \\
4-7-83 \\
8-30-83\end{array}$ & $\begin{array}{l}2.10 \\
1.14 \\
1.23 \\
2.45 \\
1.58\end{array}$ \\
\hline 01304820 & $\begin{array}{l}\text { Speonk River at } \\
\text { Speonk, N.Y. }\end{array}$ & $\begin{array}{l}\text { Lat } 40^{\circ} 49^{\prime} 06^{\prime \prime} \text {, long } 72^{\circ} 41^{\prime} 29^{\prime \prime} \text {, } \\
\text { Suffolk County, at culvert } \\
\text { on State Highway } 27 \mathrm{~A}, 0.75 \\
\text { mi }(1.21 \mathrm{~km}) \text { east of Speonk. }\end{array}$ & $\begin{array}{r}7-22-82 \\
9-8-82 \\
12-27-82 \\
4-7-83 \\
8-30-83\end{array}$ & $\begin{array}{l}0.06 \\
0.06 \\
0.75 \\
1.66 \\
0.59\end{array}$ \\
\hline
\end{tabular}




\begin{tabular}{|c|c|c|c|c|}
\hline $\begin{array}{l}\text { Station } \\
\text { number }\end{array}$ & Station name & Location & Date & $\begin{array}{l}\text { Disçharge } \\
\left(\mathrm{ft}^{3} / \mathrm{s}\right)\end{array}$ \\
\hline 01304830 & $\begin{array}{l}\text { East River at } \\
\text { Eastport, N.Y. }\end{array}$ & $\begin{array}{l}\text { Lat } 40^{\circ} 49^{\prime} 24^{\prime \prime}, \text { long } 72^{\circ} 43^{\prime} 02^{\prime \prime}, \\
\text { Suffolk County, } 15 \mathrm{ft}(5 \mathrm{~m}) \\
\text { upstream from culvert on } \\
\text { Long Island Rainroad, } 200 \mathrm{ft} \\
(60 \mathrm{~km}) \text { south of State } \\
\text { Highway } 27 \mathrm{~A}, 0.5 \mathrm{mi}(0.8 \mathrm{~km}) \\
\text { east of Eastport. }\end{array}$ & $\begin{array}{r}7-22-82 \\
9-8-82 \\
11-10-82 \\
12-27-82 \\
8-30-83\end{array}$ & $\begin{array}{l}0.76 \\
1.00 \\
0.51 \\
1.13 \\
1.96\end{array}$ \\
\hline 01304860 & $\begin{array}{l}\text { Seatuck Creek at } \\
\text { Eastport, N.Y. }\end{array}$ & $\begin{array}{l}\text { Lat } 40^{\circ} 39^{\prime} 30^{\prime \prime}, \text { long } 72^{\circ} 43^{\prime} 43^{\prime \prime}, \\
\text { Suffolk County, } 15 \mathrm{ft}(5 \mathrm{~m}) \\
\text { downstream from culvert on } \\
\text { State Highway } 27 \mathrm{~A} \text {, at } \\
\text { Eastport. }\end{array}$ & $\begin{array}{r}7-22-82 \\
9-8-82 \\
11-10-82 \\
5-3-83 \\
8-30-83\end{array}$ & $\begin{array}{l}2.20 \\
2.40 \\
2.05 \\
8.91 \\
2.26\end{array}$ \\
\hline 01304900 & $\begin{array}{l}\text { Little Seatuck Creek } \\
\text { at Eastport, N.Y. }\end{array}$ & $\begin{array}{l}\text { Lat } 40^{\circ} 49^{\prime} 12^{\prime \prime}, \text { long } 72^{\circ} 44^{\prime} 23^{\prime \prime} \text {, } \\
\text { Suffolk County, at culvert } \\
\text { on Moriches Blvd., } 0.75 \mathrm{mi} \\
(1.21 \mathrm{~km}) \text { southwest of } \\
\text { Eastport. }\end{array}$ & $\begin{array}{r}7-22-82 \\
9-8-82 \\
11-10-82 \\
5-3-83 \\
8-30-83\end{array}$ & $\begin{array}{l}0.75 \\
1.00 \\
1.19 \\
7.04 \\
3.32\end{array}$ \\
\hline 01304960 & $\begin{array}{l}\text { Forge River at } \\
\text { Moriches, N.Y. }\end{array}$ & $\begin{array}{l}\text { Lat } 40^{\circ} 48^{\prime} 22^{\prime \prime}, \text { long } 72^{\circ} 50^{\prime} 00^{\prime \prime} \text {, } \\
\text { Suf folk County, at culvert } \\
\text { on State Highway } 27 \mathrm{~A} \text {, at } \\
\text { Moriches. }\end{array}$ & $\begin{array}{r}7-22-82 \\
9-7-82 \\
11-10-82 \\
9-15-83\end{array}$ & $\begin{array}{l}4.60 \\
2.90 \\
3.17 \\
6.11\end{array}$ \\
\hline 01304990 & $\begin{array}{l}\text { Carmans River at } \\
\text { Middle Island, } \\
\text { N.Y. }\end{array}$ & $\begin{array}{l}\text { Lat } 40^{\circ} 51^{\prime} 47^{\circ}, \text {, long } 72^{\circ} 56^{\prime} 35^{\prime \prime} \text {, } \\
\text { Suffolk County, at culvert on } \\
\text { East Bartlett Road, } 0.75 \mathrm{mi} \\
(1.21 \mathrm{~km}) \text { south of Middle } \\
\text { Island, and } 3.0 \mathrm{mi}(4.8 \mathrm{~km}) \\
\text { upstream from gaging station } \\
\text { at Yaphank. }\end{array}$ & $\begin{array}{r}7-30-82 \\
9-14-82 \\
11-8-82 \\
5-11-83 \\
9-14-83\end{array}$ & $\begin{array}{l}1.70 \\
0.84 \\
0.39 \\
4.84 \\
2.10\end{array}$ \\
\hline 01304995 & $\begin{array}{c}\text { Carmans River near } \\
\text { Yaphank, N.Y. }\end{array}$ & $\begin{array}{l}\text { Lat } 40^{\circ} 50^{\prime} 29^{\prime \prime}, \text { long } 72^{\circ} 56^{\prime} 13^{\prime \prime} \text {, } \\
\text { Suf folk County, } 25 \mathrm{ft} \text { down- } \\
\text { stream from Mili Road, } 1.2 \\
\text { mi }(1.9 \mathrm{~km}) \text { northwest of } \\
\text { Yaphank, and } 1.9 \mathrm{mi}(3.1 \mathrm{~km}) \\
\text { upstream from gaging station } \\
\text { at Yaphank. }\end{array}$ & $\begin{array}{r}7-30-82 \\
9-14-82 \\
11-8-82 \\
5-11-83 \\
9-14-83\end{array}$ & $\begin{array}{r}11 \\
13 \\
9.65 \\
16.12 \\
11.90\end{array}$ \\
\hline 01304998 & $\begin{array}{l}\text { Carmans River, } \\
\text { below Lower Lake } \\
\text { at Yaphank, N.Y. }\end{array}$ & $\begin{array}{l}\text { Lat } 40^{\circ} 50^{\prime} 07^{\prime \prime}, \text { long } 72^{\circ} 55^{\prime} 01^{\prime \prime} \text {, } \\
\text { Suf folk County, at culvert on } \\
\text { Yaphank Avenue, at Yaphank, } \\
\text { and } 0.7 \mathrm{mi}(1.1 \mathrm{~km}) \text { upstream } \\
\text { from gaging station at } \\
\text { Yaphank. }\end{array}$ & $\begin{array}{r}7-30-82 \\
9-14-82 \\
11-8-82 \\
9-14-83\end{array}$ & $\begin{array}{l}15 \\
13 \\
8.8 \\
17\end{array}$ \\
\hline 01305040 & $\begin{array}{l}\text { Carmans River at } \\
\text { South Haven, } \\
\text { N.Y. }\end{array}$ & $\begin{array}{l}\text { Lat } 40^{\circ} 48^{\prime} 09^{\prime \prime}, \text { long } 72^{\circ} 53^{\prime} 09^{\prime \prime}, \\
\text { Suffolk County, 50 ft (15 m) } \\
\text { upstream from culvert on } \\
\text { State Highway } 27 \text {, at South } \\
\text { Haven, and } 2.6 \mathrm{mi}(4.2 \mathrm{~km}) \\
\text { downstream from gaging station } \\
\text { at Yaphank. }\end{array}$ & $\begin{array}{r}7-30-82 \\
9-14-82 \\
11-8-82 \\
9-14-83\end{array}$ & $\begin{array}{l}73 \\
60 \\
62 \\
50\end{array}$ \\
\hline
\end{tabular}

Reference: U.S. Geological Survey. 
Table 10.--Concentrations of nitrate-nitrogen in water from selected Suffolk County Department of Health Services observation wells in the Pine Barrens, 1972-82.

[Locations are shown in fig. 2.]

\begin{tabular}{|c|c|c|c|c|c|}
\hline We11 no. 1 & Date & $\begin{array}{l}\text { Nitrate- } \\
\text { nitrogen } \\
\text { (mg/l) }\end{array}$ & We11 no. & Date & $\begin{array}{l}\text { Nitrate- } \\
\text { nitrogen } \\
\text { (mg/L) }\end{array}$ \\
\hline $45724 \mathrm{STP}$ & $\begin{array}{r}12-6-72 \\
3-11-75 \\
10-18-77 \\
10-15-80 \\
4-15-82 \\
10-7-82\end{array}$ & $\begin{array}{r}1.40 \\
3.00 \\
4.20 \\
5.20 \\
10.90 \\
6.60\end{array}$ & $\begin{array}{l}47225 \\
(\text { cont'd) }\end{array}$ & $\begin{array}{r}10-19-81 \\
1-27-82 \\
3-29-82 \\
5-10-82 \\
7-13-82 \\
10-15-82 \\
11-18-82\end{array}$ & $\begin{array}{l}9.30 \\
8.20 \\
6.30 \\
6.70 \\
6.20 \\
7.20 \\
6.20\end{array}$ \\
\hline 46966 & $\begin{array}{r}10-28-74 \\
12-26-74 \\
4-30-76 \\
7-20-77 \\
6-5-79 \\
1-24-80 \\
5-29-80 \\
7-9-80 \\
9-15-80 \\
12-8-80 \\
2-17-81 \\
5-4-81 \\
7-15-81 \\
9-21-81 \\
11-23-81 \\
1-6-82 \\
3-16-82 \\
5-12-82 \\
7-13-82 \\
10-15-82 \\
11-18-82\end{array}$ & $\begin{array}{r}.01 \\
.03 \\
.02 \\
<.02 \\
.03 \\
.02 \\
.06 \\
.04 \\
.04 \\
<.04 \\
<.04 \\
<.02 \\
<.02 \\
<.04 \\
<.02 \\
<.02 \\
<.02 \\
.02 \\
<.04 \\
<.04 \\
<.020 \\
.04\end{array}$ & 47226 & $\begin{array}{r}3-30-73 \\
8-9-74 \\
5-30-75 \\
5-12-76 \\
11-19-76 \\
7-30-79 \\
8-16-79 \\
10-19-79 \\
2-7-80 \\
3-21-80 \\
5-4-82 \\
7-8-82 \\
9-20-82 \\
12-2-82 \\
12-13-82 \\
\\
3-29-73 \\
8-9-74 \\
5-30-75 \\
5-12-76 \\
11-19-76\end{array}$ & $\begin{array}{r}.020 \\
<.01 \\
.01 \\
<.02 \\
<.02 \\
.02 \\
.02 \\
.06 \\
<.02 \\
.022 \\
<.02 \\
<.04 \\
<.04 \\
<.020 \\
<.40 \\
<.020 \\
\\
\quad .05 \\
.041 \\
<.41 \\
<.01 \\
<.02 \\
<.02\end{array}$ \\
\hline 47225 & $\begin{array}{r}8-14-74 \\
8-29-74 \\
5-27-75 \\
5-10-76 \\
3-1-78 \\
2-8-79 \\
5-17-79 \\
2-22-80 \\
3-5-80 \\
7-8-80 \\
9-16-80 \\
12-17-80 \\
5-13-81 \\
6-30-81 \\
9-28-81\end{array}$ & $\begin{array}{l}3.50 \\
3.12 \\
5.40 \\
5.00 \\
4.00 \\
4.30 \\
3.20 \\
2.60 \\
2.30 \\
2.90 \\
2.60 \\
6.40 \\
7.40 \\
7.50 \\
8.30\end{array}$ & 47228 & $\begin{array}{r}7-30-79 \\
8-16-79 \\
10-9-79 \\
2-7-80 \\
3-21-80 \\
5-4-82 \\
7-8-82 \\
9-20-82 \\
12-2-82 \\
12-13-82 \\
8-9-74 \\
5-30-75 \\
5-12-76 \\
11-19-76\end{array}$ & $\begin{array}{r}.05 \\
.03 \\
<.02 \\
.06 \\
<.02 \\
<.040 \\
<.40 \\
<.020 \\
<.40 \\
<.020 \\
<.01 \\
<.01 \\
<.02 \\
.02\end{array}$ \\
\hline
\end{tabular}

1 STP = Sewage-treatment plant 
Table 10.-Concentrations of nitrate-nitrogen in water from selected Suffolk County Department of Health Services observation wells in the Pine Barrens, 1972-82 (continued)

[Locations are shown in fig. 2.]

\begin{tabular}{|c|c|c|c|c|c|}
\hline We11 no. ${ }^{1}$ & Date & $\begin{array}{l}\text { Nitrate- } \\
\text { nitrogen } \\
\text { (mg/e) }\end{array}$ & We11 no. & Date & $\begin{array}{l}\text { Nitrate- } \\
\text { nitrogen } \\
\text { (mg/L) }\end{array}$ \\
\hline $\begin{array}{l}47228 \\
(\text { cont 'd) }\end{array}$ & $\begin{array}{r}1-25-79 \\
6-19-79 \\
8-8-79 \\
8-14-79 \\
2-7-80 \\
3-25-80 \\
8-11-80 \\
9-3-80 \\
10-29-80 \\
1-27-81 \\
3-31-81 \\
5-26-81 \\
11-5-81 \\
1-26-82 \\
4-7-82 \\
5-4-82 \\
6-17-82 \\
7-7-82 \\
9-27-82 \\
11-29-82\end{array}$ & $\begin{array}{r}<0.02 \\
.07 \\
.02 \\
<.040 \\
<.02 \\
<.02 \\
.024 \\
<.04 \\
<.04 \\
<.02 \\
<.02 \\
.40 \\
<.05 \\
<.04 \\
.04 \\
<.04 \\
<.04 \\
<.04 \\
<.04 \\
.04 \\
.04 \\
<.20\end{array}$ & $\begin{array}{l}47229 \\
\text { (cont'd) } \\
47230\end{array}$ & $\begin{array}{r}9-27-82 \\
11-29-82 \\
\\
3-28-73 \\
8-8-74 \\
8-14-75 \\
3-30-76 \\
11-5-76 \\
7-25-77 \\
5-10-79 \\
4-7-80 \\
2-17-81 \\
8-25-81 \\
11-19-81 \\
5-6-82 \\
1-21-82 \\
9-20-82 \\
12-16-82 \\
\\
8-8-74 \\
7-7-75\end{array}$ & $\begin{array}{r}1.40 \\
1.10 \\
\\
.80 \\
.07 \\
.01 \\
.02 \\
.11 \\
.03 \\
.05 \\
.03 \\
.10 \\
.15 \\
.40 \\
<.04 \\
<.02 \\
<.02 \\
<.40 \\
<.01 \\
<.01\end{array}$ \\
\hline 47229 & $\begin{array}{r}3-27-73 \\
8-9-74 \\
5-30-75 \\
5-12-76 \\
11-19-76 \\
1-25-78 \\
6-19-79 \\
8-8-79 \\
2-7-80 \\
3-5-80 \\
3-25-80 \\
8-11-80 \\
9-3-80 \\
10-29-80 \\
1-27-81 \\
3-31-81 \\
5-26-81 \\
11-5-81 \\
1-26-82 \\
4-7-82 \\
5-4-82 \\
6-17-82 \\
7-7-82\end{array}$ & $\begin{array}{r}1.00 \\
.50 \\
1.02 \\
.43 \\
.86 \\
.74 \\
.57 \\
.55 \\
1.10 \\
.60 \\
1.20 \\
.95 \\
.80 \\
.83 \\
.90 \\
.80 \\
1.40 \\
3.20 \\
.79 \\
1.20 \\
1.20 \\
1.10 \\
.90\end{array}$ & $\begin{array}{l}47488 \text { STP } \\
47745\end{array}$ & $\begin{array}{r}11-10-76 \\
4-30-79 \\
1-10-80 \\
2-10-81 \\
8-11-81 \\
11-23-81 \\
5-11-82 \\
7-14-82 \\
9-14-82 \\
12-20-82 \\
5-22-73 \\
\\
7-6-73 \\
8-14-74 \\
10-3-74 \\
5-19-75 \\
5-10-76 \\
1-26-79 \\
5-17-79 \\
2-25-80 \\
7-8-80 \\
9-18-80\end{array}$ & $\begin{array}{r}<.02 \\
.07 \\
.05 \\
<.02 \\
.09 \\
<.02 \\
<.40 \\
<.40 \\
<.20 \\
<.20 \\
\\
.30 \\
\\
4.70 \\
1.71 \\
.91 \\
4.10 \\
6.60 \\
1.70 \\
.93 \\
3.00 \\
3.60 \\
1.50\end{array}$ \\
\hline
\end{tabular}


Table 10.--Concentrations of nitrate-nitrogen in water from selected Suffolk County Department of Health Services observation wells in the Pine Barrens, 1972-82 (continued)

[Locations are shown in fig. 2.]

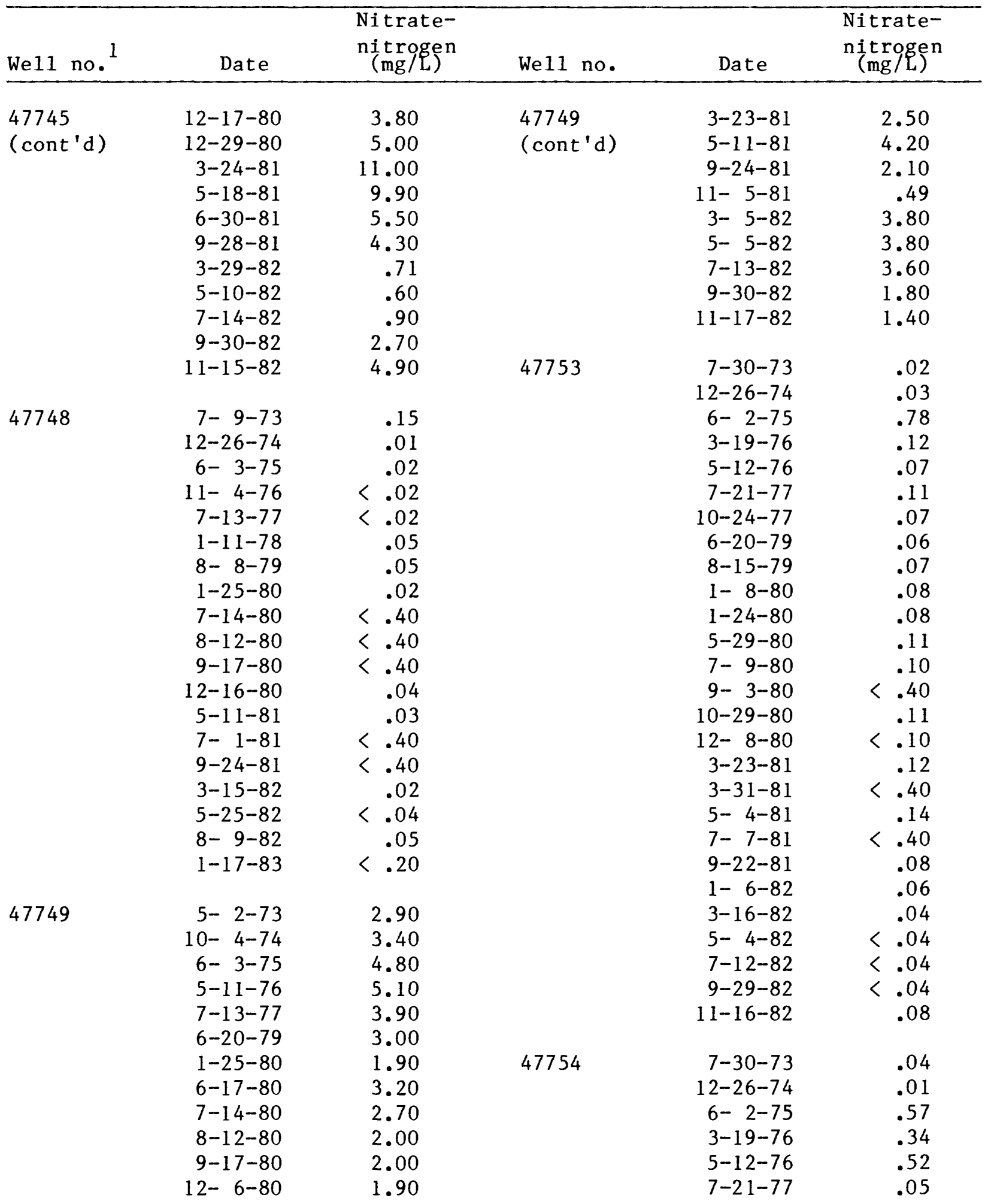


Table 10.--Concentrations of nitrate-nitrogen in water from selected Suffolk County Department of Health Services observation wells in the Pine Barrens, 1972-82 (continued)

[Locations are shown in fig. 2.]

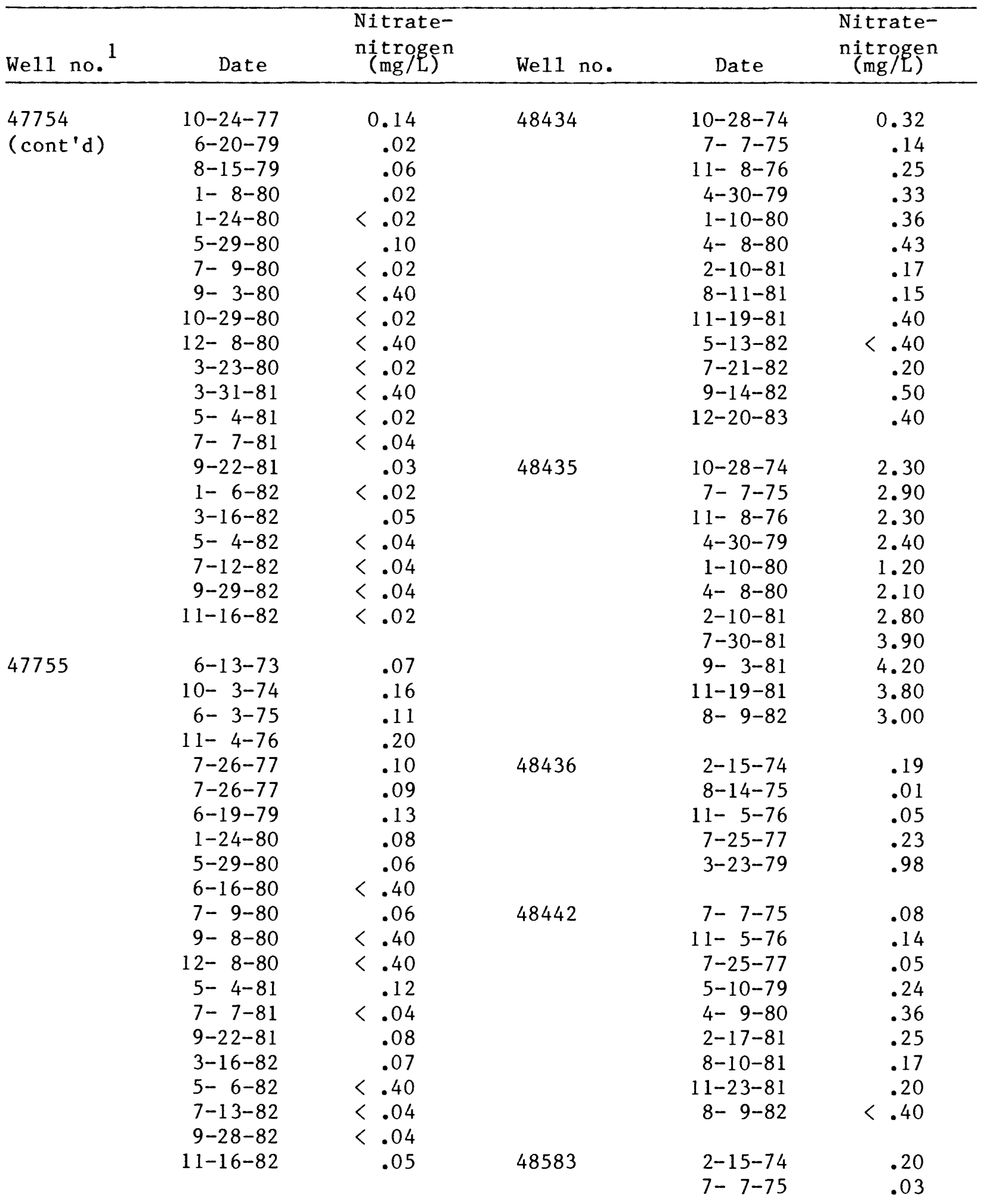


Table 10.--Concentrations of nitrate-nitrogen in water from selected Suffolk County Department of Health Services observation wells in the Pine Barrens, 1972-82 (continued)

[Locations are shown in fig. 2.]

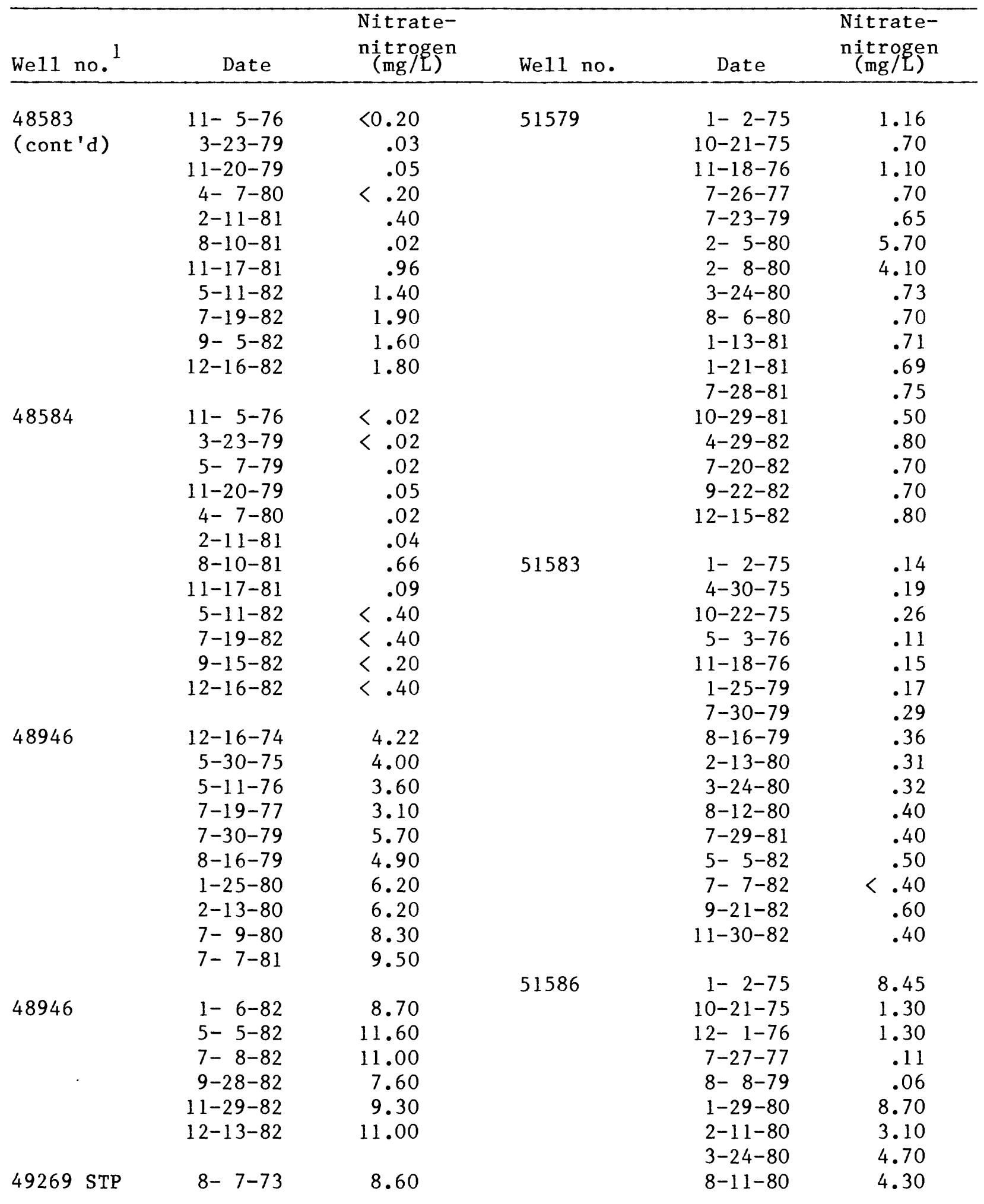


Table 10.--Concentrations of nitrate-nitrogen in water from selected Suffolk County Department of Health Services observation wells in the Pine Barrens, 1972-82.

[Locations are shown in fig. 2.]

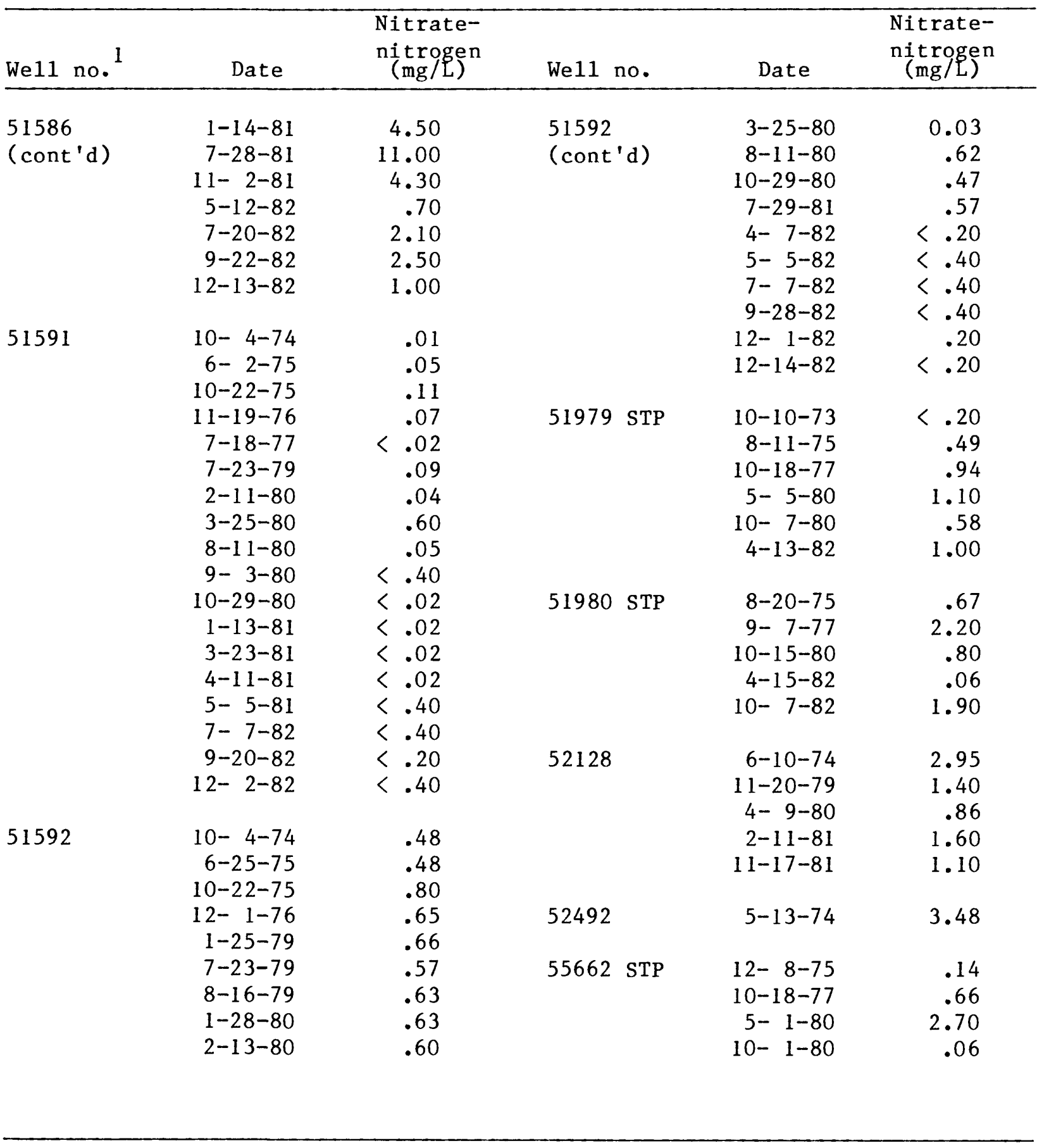

STP, Sewage-treatment plant 


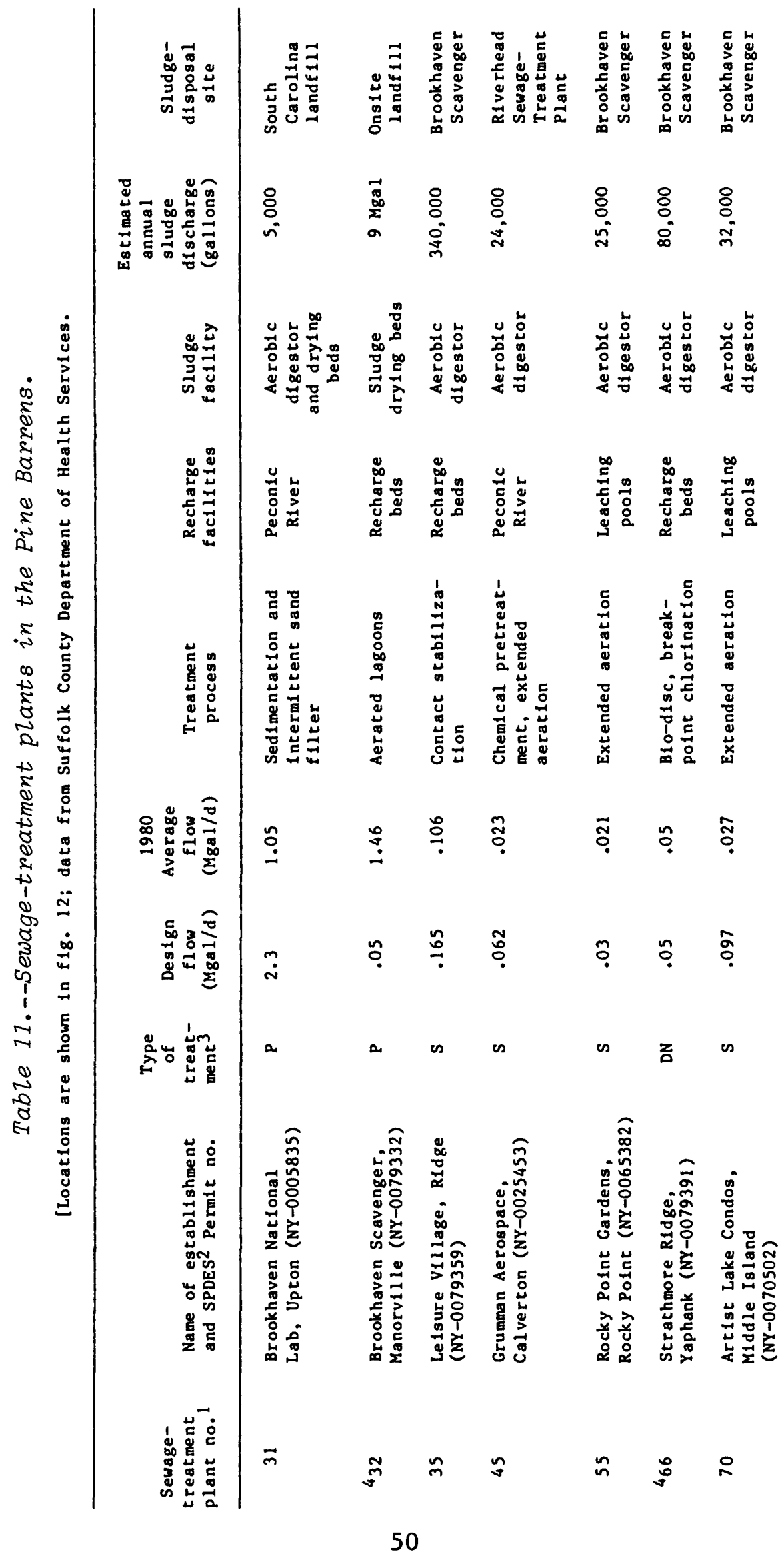




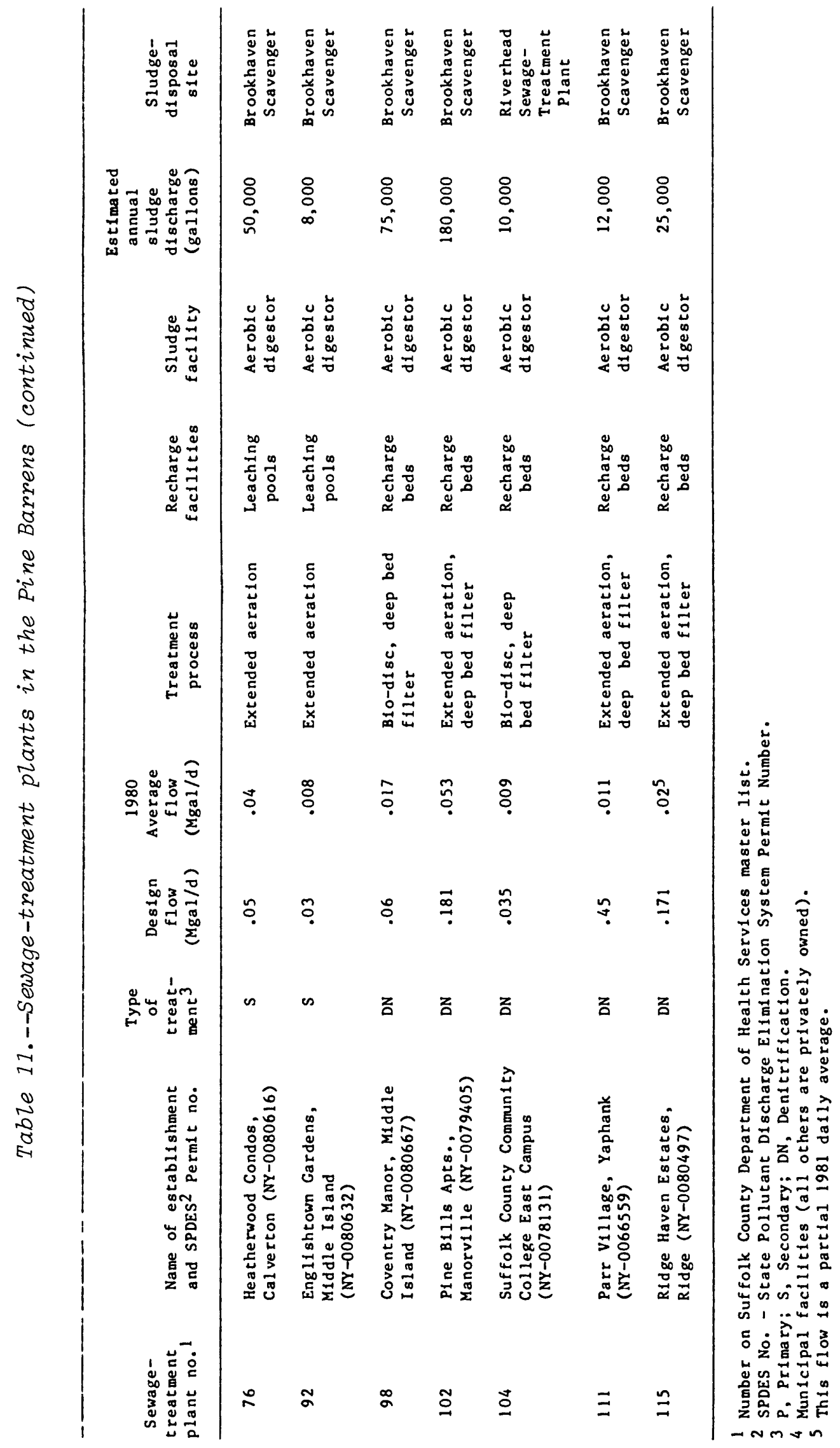




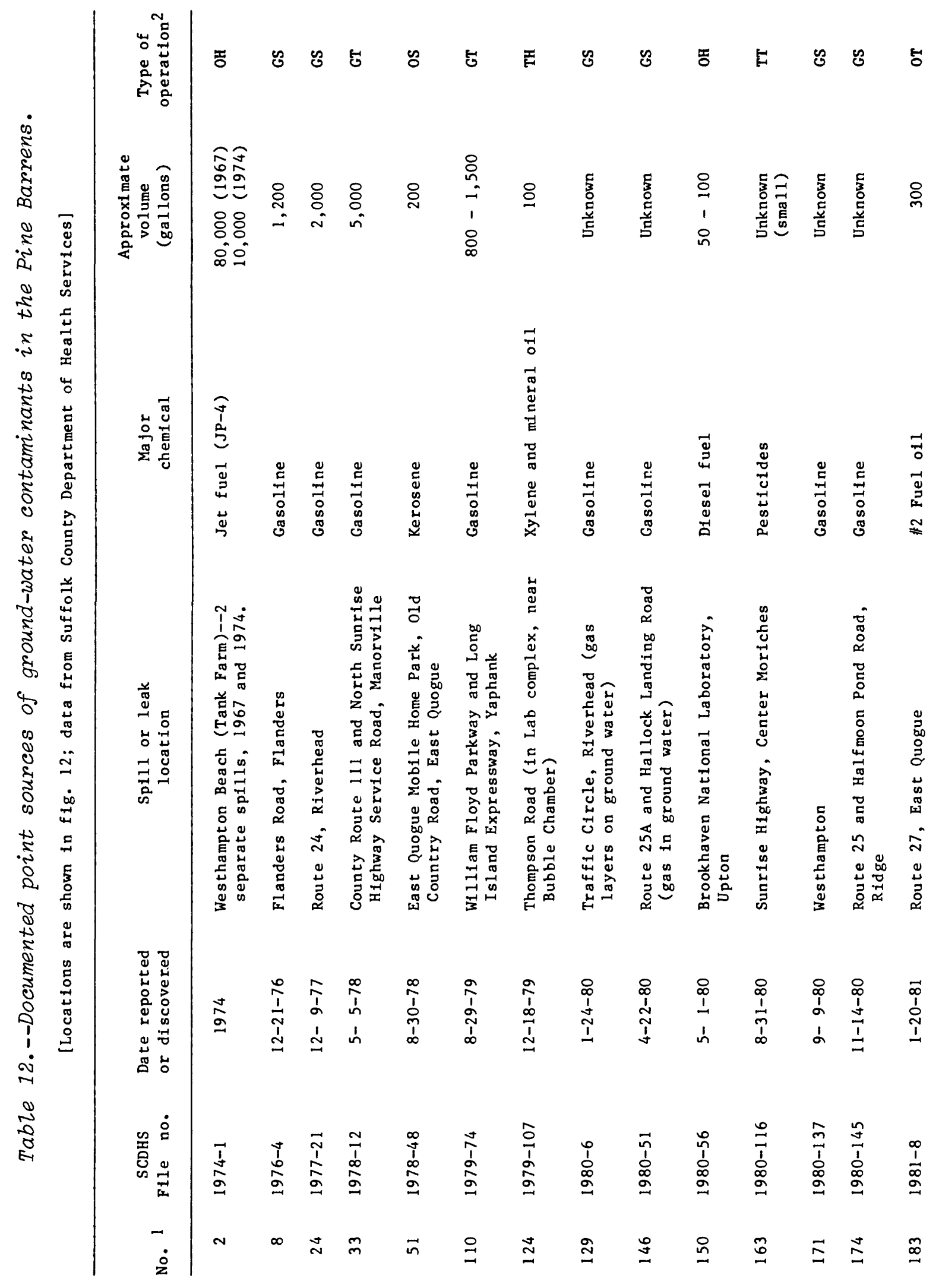




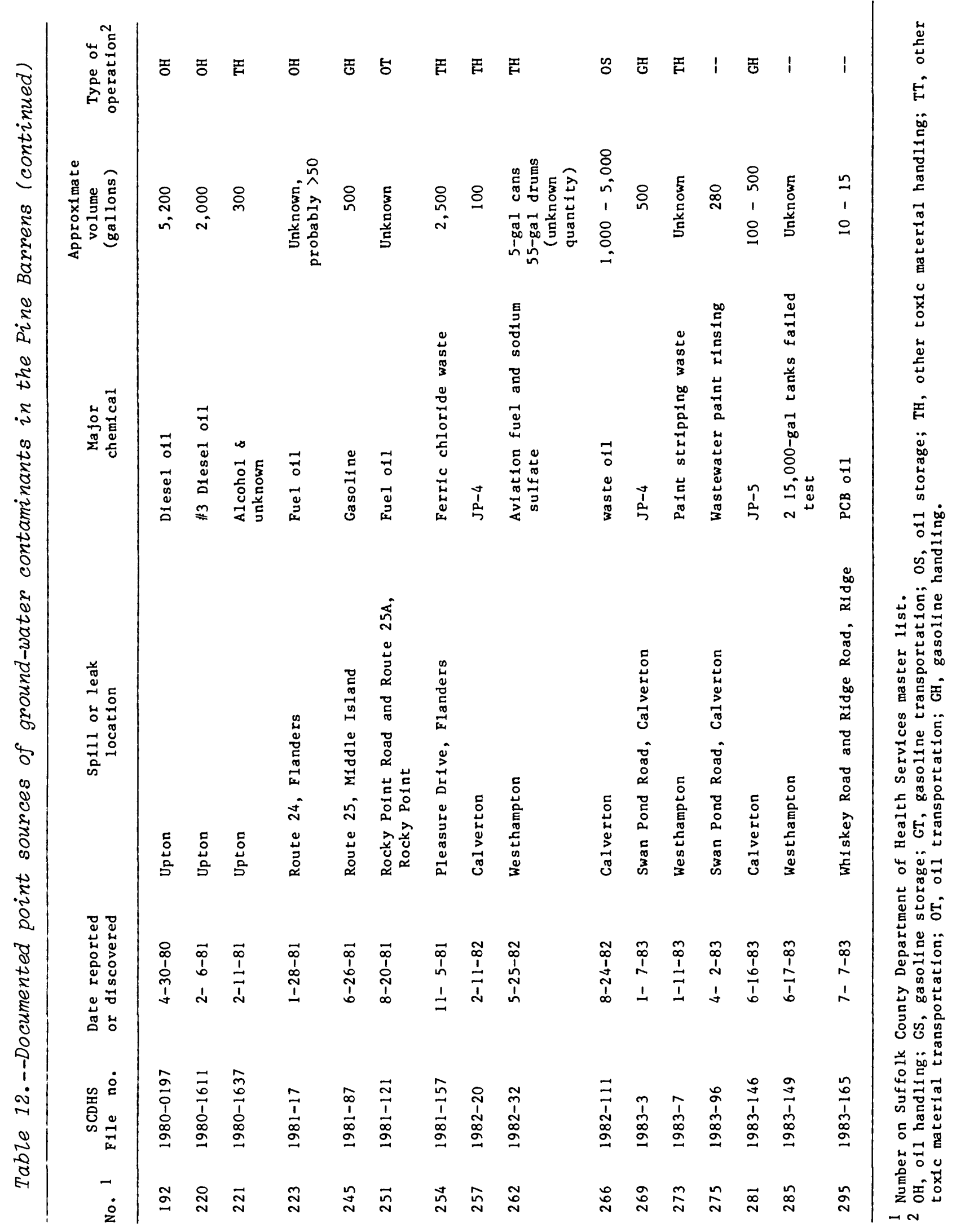

